\title{
Corporate Governance and Default Risk in Financial Firms over the Post Financial Crisis Period: International Evidence
}

\author{
Qiao Tu \\ A Thesis \\ in The John Molson School of Business \\ Master of Science in Administration program (Finance option) \\ Presented in Partial Fulfillment of the Requirements \\ For the Master of Science in Administration \\ at Concordia University \\ Montreal, Quebec, Canada
}

September 2015

(C) Qiao Tu, 2015 


\section{CONCORDIA UNIVERSITY}

\section{School of Graduate Studies}

This is to certify that the thesis prepared

By: $\quad$ Qiao Tu

Entitled: $\quad$ Corporate Governance and Default Risk in Financial Firms over the Post Financial Crisis Period: International Evidence

and submitted in partial fulfilment of the requirements for the degree of

\section{MASTER OF SCIENCE IN ADMINISTRATION (FINANCE)}

complies with the regulations of this University and meets the accepted standards with respect to originality and quality.

Signed by the final Examining Committee:

Chair

Dr. Mahesh Sharma

Examiner

Dr. Imants Paeglis

Examiner

Dr. Yuan Wang

Supervisor

Dr. Lorne Switzer

Approved by

Graduate Program Director

2015

Dean of Faculty 


\begin{abstract}
Corporate Governance and Firm Default Risk during the Post Financial Crisis Period: International Evidence

Qiao Tu
\end{abstract}

This paper looks at the post financial crisis period, and the relationship between default risk and corporate governance for financial firms outside of North America. Default risk is captured through both credit default swap spreads (CDS) and the Black-Scholes-Merton Distance-to-Default measure (DD). Institutional ownership and board independence negatively relate to DD, while insider holdings, CEO duality, and board size positively relate to DD for the complete sample for firms. Not all of these relationships hold when using CDS spreads as a risk gauge. Relationships between board-related variables and risk are found to be continent-specific, which can explain some of the different risk responses to governance variables across risk measures. In particular, for Asian firms, most governance variables are significantly related to default risk. For European firms, on the other hand, only board size and institutional holdings are significant. 


\section{ACKNOWLEDGEMENT}

I would like to thank my supervisor, Dr. Lorne Switzer, for his patience, encouragement and assistance throughout my thesis. His suggestions during the planning and development of this thesis are valuable and constructive.

Then, I want to thank my committee members for their patience and guidance: Dr. Imants Paeglis and Dr. Yuan Wang. I would also like to extend my thanks to Dr. Jun Wang (Assistant Professor in Western University) for her suggestions and help with the CDS data.

Finally, I wish to thank my parents and all my classmates for their support and encouragement throughout my study. 


\section{Contents}

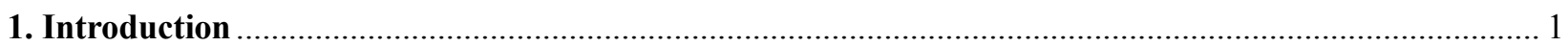

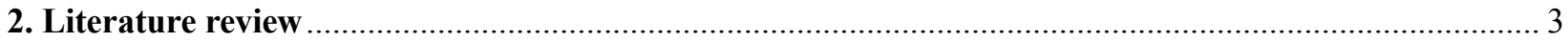

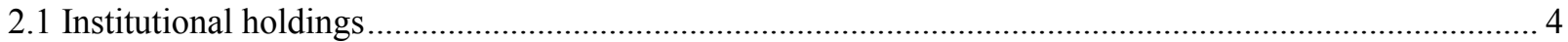

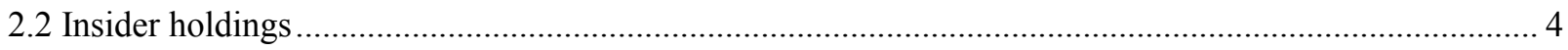

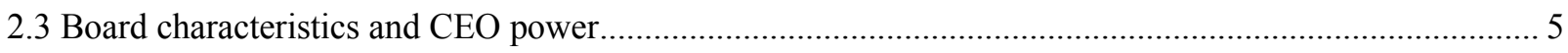

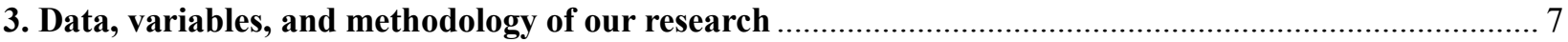

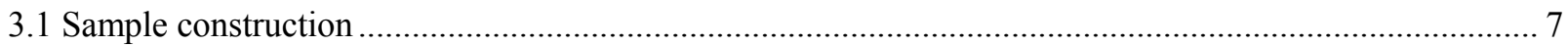

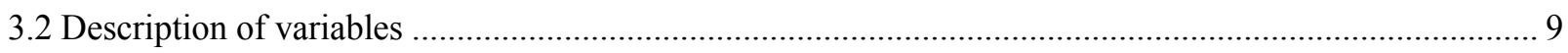

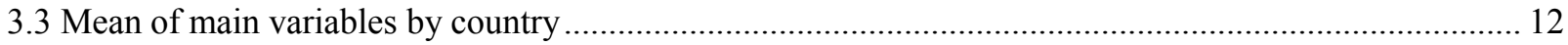

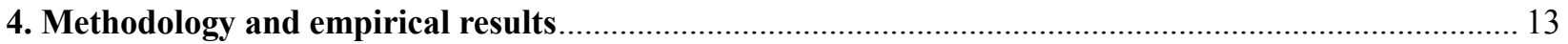

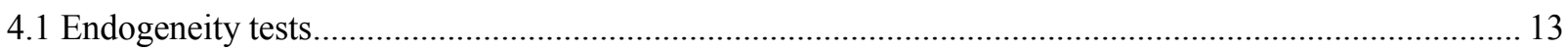

4.2 Full sample regressions without constraints................................................................................. 14

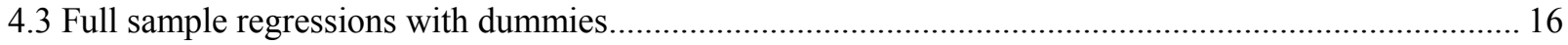

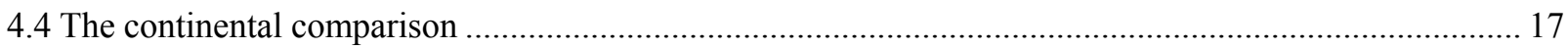

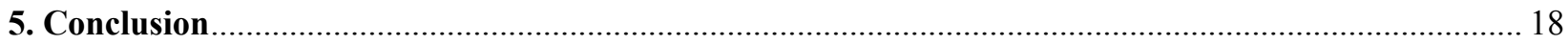




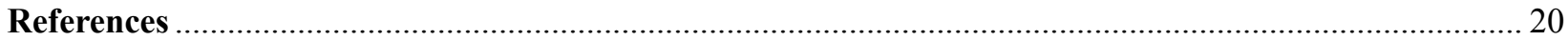

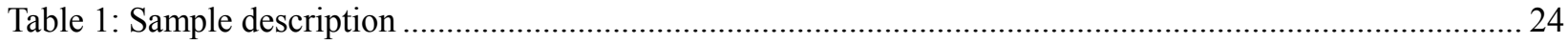

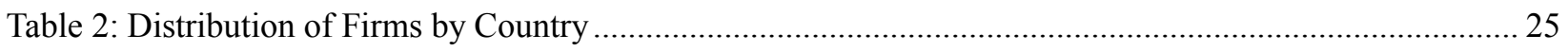

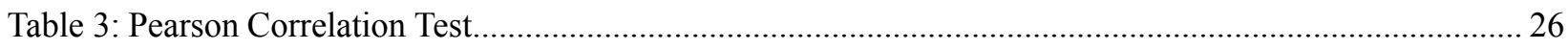

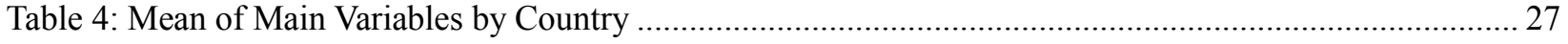

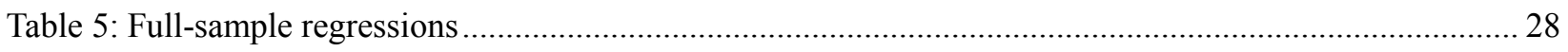

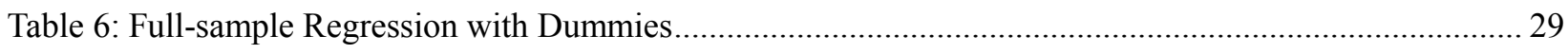

Table 7: Full-sample Regressions with Dummies (Country fixed effect) …………........................................ 30

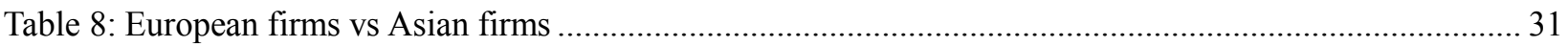

Table 9: European firms vs Asian firms (Country fixed effect) .................................................................... 33

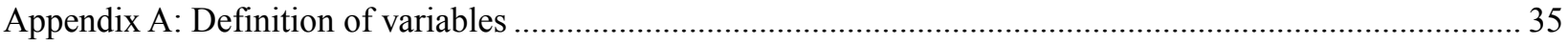

Appendix B: Generalized Method of Moments estimation overidentification \& endogeneity tests .................. 36 


\section{Introduction}

The financial crisis of 2007-08 engendered huge losses to many firms worldwide, and has been the topic of considerable research in corporate governance for the past several years. However, crisis type conditions in many international markets did not end with the US recovery. At the end of 2009, with Eurozone member states unable to bail out their over-indebted banks, the European Banking Crisis erupted, which gave rise to widespread defaults, and various stopgap banking system bailouts. For example, the Allied Irish Bank (AIB) and Bank of Ireland (BoI) in Ireland received a $€ 7$ billion rescue package in 2009 and recapitalize their assets. Greece's four biggest banks-National Bank of Greece SA, Piraeus Bank SA, Euro-bank Ergasias SA and Alpha Bank AE Greek banks have been regular recipients of emergency loans from the European Central Bank. Besides European banks, several financial firms in Asia have faced default in the post financial crisis period. Aiful Corporation, the Japanese third-largest consumer lender by assets, failed to honour maturing of loans in December of 2009 which triggered a restructuring event, and involved the payout of credit default swaps insuring \$1.3 billion of its debt.1 Neo-China Land Group, an investment holding company based in China, was downgraded by Moody's by three notches to Ca in 2009 for failing in a coupon payment of $\$ 19.5$ million on its outstanding $\$ 400$ million 2014 bonds. The IMF has dubbed the post crisis experience of different regions of the world as a reflection of the "multispeed global economy" (IMF, 2013). It has been widespread view that these conditions can be attributed to important o failures and weaknesses in corporate governance arrangements that do not safeguard against excessive risk taking of many financial services companies. A number of studies have examined the interaction of governance mechanisms and the performance of firms during the 2007-8 crisis period (e.g., Aebi, Sabato, and Schmid, 2012; Beltratti and Stulz, 2012; Erkens, Hung, Matos, 2012; Liu, Uchida, and Yang, 2012). However, few papers have actually look at the performance of non US firms in the aftermath of the crisis. Furthermore, we are unaware of any research pertaining to the impact of governance mechanisms

\footnotetext{
1 See http://www.bloomberg.com/apps/news? pid=newsarchive\&sid=aNC9J16hAatg http://www.reuters.com/article/2009/01/29/neochina-default-idUSHKG19351920090129
} 


\section{on risk for financial firms in countries outside of the US.}

The purpose of this study is to fill this gap. Similar to Switzer and Wang (2013), we use the 5-year CDS spread as a measure of firms' default risk to explore the relationship between the firms' default risk and corporate governance during post-crisis period. CDS spread has several advantages in capturing default probabilities for a number of reasons. First, unlike bonds on which spread measures of risk are measured, CDS are not in fixed supply and should be less sensitive to liquidity effects. Finally, as Garcia, Alejandro, and Yang (2009) note, unlike corporate bonds, they are less susceptible to squeezes or to become "special" with repo rates below market rates for similar maturities and credit risks. We consider a sample of firms from 28 different countries and analyze the effects of governance variables, controlling for the differences in country development and general market conditions, in addition to a set of firm level control variables. We address the possibility of selection bias and endogeneity in the analyses. As a robustness test, we also use Black-Scholes-Merton 5-year default probability as an alternative measure of firms' default risk to compare with CDS spread in the regressions.

We consider five variables to measure a firm's governance mechanism: institutional ownership, insider ownership, board independence, board size, and CEO duality. These are common variables used to measure firms' corporate governance in the extant literature (e.g. Anderson and Fraser, 2000; Bhojraj and Sengupta, 2003; Erkens, Hung, and Matos, 2012; Liu, Uchida, and Yang, 2012; Switzer and Wang, 2013). We also use instrumental variable estimation methods to address the potential endogeneity of institutional ownership. In addition, as a further robustness check we also perform the analyses Black-Scholes-Merton Distance-to-Default measure as a proxy for default risk. For our complete international sample, we find that institutional ownership is negatively related to firms' default risk, indicating the monitoring effect of institutions on the company (Crutchley et al., 1999). Board size, is positively related to CDS spread, which suggests that larger boards may induce firms to increase risk-taking. Consistent with Podder et al. (2013) who look at insurance firms find that board independence positively affects risk-taking behavior for a broader group of financial firms. The results based on the default probability measure 
are consistent with Switzer and Wang (2013) who find that board independence and board size negatively affect firms' default risk in US financial firms. Finally, we perform the analyses separately for European and Asian firms, which account for approximately $90 \%$ of the sample. We find that part of the relationships from previous regressions still hold for Asian and European firms. However, for Asian-firms, as opposed to European-firms, an inverse relationship between board independence and firms' risk is observed, using both the CDS-spread and default-probability regressions. While board independence is positively related to CDS spread, it is negatively related to default probability. We conjecture that this result may be due to some unobserved characteristics of CDS of Asian financial firms.

The rest of paper proceeds as follows. Section 2 reviews the relevant literature; Section 3 describes the data and sample construction; Section 4 describes the methodology and provides empirical results. We conclude in Section 5.

\section{Literature review}

Jensen and Meckling (1976) define the agency relationship as relationship in which one or more owners (the principal(s)) delegate another entity (the agent) to perform some services on their behalf. In a corporation, the principals refer to stockholders while the agent refers to the firm's management staff including the CEO. Due to conflicts of interest associated with the separation of ownership from control, agents may not act in the best interests of principals. Bhojraj and Sengupta (2003) note that governance mechanisms can reduce default risk through mitigating agency costs, monitoring managerial performance and reducing information asymmetry between the firm and the lenders. In addition, firm's risk-taking behavior can also be influenced by such conflicts (see e.g. Demsetz, Saidenberg and Strahan (1997); Pathan (2009); Liu and Jiraporn (2010)) Several authors have examined relationships between governance mechanisms on bank performance and on risk taking (e.g., Saunders, Strock, and Travlos, 1990; Gorton and Rosen, 1992; Anderson and Fraser, 2000; Caprio, Laeven, and Levine, 2007; Laeven and Levine, 2009; Pathan, 2009, Fahlenbrach and Stulz, 2011, Beltratti and Stulz, 2012). Thus, in the following review, we try to 
describe the relationship between corporate governance and firms' default risk from four important aspects of corporate governance: (1) institutional ownership; (2) insider ownership; (3) board characteristics; and (4) CEO power.

\subsection{Institutional holdings}

The impact of institutional holdings, or ownership levels on default risk has been examined in several papers, with mixed and conflicting results. For example, Crutchley et al. (1999) claim that high institutional holdings can enhance the monitoring effect and reduce the agency problem. Bhojraj and Sengupta (2003) find that firms with higher institutional holdings benefit from lower bond yields and higher ratings on their new bond issues, thereby reducing the firm's default risk. In contrast, Erkens, Hung, and Matos (2012) investigate the impact of corporate governance on financial firms' performance during 2007-2008 financial crisis and find that institutional holdings are negatively related to stock returns (see also e.g., Aebi, Sabato, and Schmid, 2012). . This suggests that firms with higher institutional ownership were willing to take more risk before the crisis, resulting in bad performance during the crisis. Similarly, Switzer and Wang (2013) find that institutional ownership has a negative relationship with the credit risk levels of US commercial banks, after controlling for firm specific characteristics of such banks.

In our research, we hypothesize that institutional ownership negatively relates to firms' default risk, as measured by CDS spread, implying that external monitoring from institutions benefits a firm in terms of its risk-taking behavior. We therefore have the following hypothesis:

H1: Institutional ownership is negatively related to a firm's default risk.

\subsection{Insider holdings}

We define insider holdings as the percentage of outstanding shares currently held by insiders. Insiders are commonly referred to "management staff" (Jensen and Meckling, 1976). Similarly, managerial ownership is defined as the percentage ownership by key officers and directors in a company (e.g., Anderson and Fraser, 2000, and Liu, Uchida, and Yang, 2012). Liu, Uchida, and Yang (2012) use the change in Tobin's Q as a proxy for change in firm value to explore 
its association with corporate governance in China during the past global financial crisis. They find that managerial holdings are positively associated with firm value changes for state-owned enterprises. Their finding is consistent with Li et al. (2007) who show that firms with higher managerial ownership outperform those with lower managerial ownership in terms of operating and net return on assets. Anderson and Fraser (2000) find mixed results on the relationship between bank governance and its risk-taking, measuring managerial holdings as the aggregate percentage of shares held by all officers and directors of the bank. Specifically, managerial holdings positively affected a firm's total risk and its specific risk in the late 1980s when the banking industry was relatively less regulated and the entire industry was in a state of financial stress. However, in 1992 - 1994 period following legislation (FIRREA and FIDICIA) designed to restrict risk-taking and after the industry returned to profitability, managerial holdings were negatively related to the risk of those banks. Saunders, Strock, and Travlos (1990) also present evidence on banks that banks managers with high stock holdings prefer high risk projects. Contrarily, banks managers holding a relatively small percentage of shares of the bank tend to reduce bank risk-taking, considering that it could maximize their own utility and protect their jobs. In addition, Gorton and Rosen (1992) point out that increased insider holdings tend to encourage managers to raise more risk loans than relatively safe loans in 1980s.

We hypothesize that insider ownership has a positive relationship with firms' default risk. Due to entrenchment effect, managers with higher holdings tend to perform more aggressively, thereby increase the default risk of the company:

H2: Insider ownership has a positive association with a firm's default risk.

\subsection{Board characteristics and CEO power}

We use board independence (i.e., the percentage of independent directors in the board) and board size (i.e., the number of board members) to describe board characteristics, and use CEO duality (i.e., variable measures whether CEO is also the chairman of board or not) to measure CEO power.

Based on the sample firms that were at the center of financial crisis from 28 countries, 
Erkens, Hung, and Matos (2012) find that more independent board is linked with worse stock returns, implying that a board with higher proportion of independent directors prefer to raise more equity capital at depressed stock prices during the crisis which may result in wealth transfer from shareholders to debtholders. In fact their study does show a big loss to those companies during the 2007-2008 financial crisis. In contrast, Pathan (2009) finds that strong bank boards, particularly with small board size and less independent directors, can increase a bank's risk-taking. When concerning firms' credit ratings, Skaife, Collins, and LaFond (2006) find that board independence is positively associated with credit ratings. In other words, the higher percentage of independent directors in a board is linked with higher firm's credit rating and lower default risk. In addition, in terms of financial firms and non-financial firms, the evidence shows that board independence negatively affects firms' default risk in financial firms rather than non-financial firms (Switzer and Wang, 2013). Furthermore, Switzer and Wang (2013) show again that board independence and board size have negative influence on US commercial banks' default risk. Even when they restrict the sample firms to consider the joint effects of all corporate governance variables, the result on board size still remain. The same relationship between board size and banks' buy-and-hold stock returns in recent financial crisis is also found by Aebi, Sabato, and Schmid (2012). In measuring the board independence, Beltratti and Stulz (2012) also construct an index (higher for more independent directors and lower for less independent directors in boards) to measure whether or not a board is friendly. They find that banks with more shareholder-friendly boards (higher value of index) performed significantly worse than other banks during financial crisis, posing a challenge to those papers which argue that poor bank governance was the major cause of crisis.

According to Imhoff (2003), CEO significantly influences the membership of corporate boards and it is normal for the chairman of the board to be either the current or former CEO of a company. Since corporate board is built to oversee management on behalf of shareholders, it is debatable to have CEO on the board being supervised and serving. Thus, duality can possibly affect a firm's default risk via the influence on membership of corporate boards. Skaife, Collins, and LaFond (2006) indicate that CEO power is negatively related to firms' credit ratings. However, 
Pathan (2009) uses a sample of 212 large US bank holding companies over 1997-2004 and finds that $\mathrm{CEO}$ power, measured by $\mathrm{CEO}$ duality, negatively relates to the risk of a bank, implying that CEO prefers lower risk when he/she is the chairman of the board in order to protect bank's undiversified assets and his/her fixed salary. Some pervious literature finds no significant relation of board independence and CEO power to a firm's risk (see e.g. Liu, Uchida, and Yang, 2012; Aebi, Sabato, and Schmid, 2012).

Considering the mixed evidence on board characteristics and CEO power from previous literature, we have the following two hypotheses:

H3: Board independence and board size are negatively associated with a firm's default risk;

H4: CEO power has no significant influence on a firm's default risk.

\section{Data, variables, and methodology of our research}

\subsection{Sample construction}

Since our research focuses on post-crisis period, we choose our sample from 2010 to 2012. Except CDS spread, all of our other data are obtained from Bloomberg database. The year 2007 and 2008 have been regarded as the period of subprime mortgages (Ryan, 2008; Erkens, Hung, and Matos, 2012). However, in order to clarify the boundary of financial crisis without overlapping with post financial crisis, we still select year 2010 rather than year 2009, leaving one-year gap between two periods.

Our sample includes 117 financial firms located outside of North America. Our firmselection criteria are as follows. First, we obtain all financial firms outside of North America from Bloomberg database. There are 11140 observations in total. Second, we restrict our sample to financial firms having traded CDS information from Markit database - a global financial information services company providing independent data, valuations and trade processing across all asset classes. After merging the two databases, 10993 firms are dropped and the number of sample firms reduces to 145 . Third, we delete firms with missing data on corporate governance and fundamentals from Bloomberg database. Our final sample consists of 117 financial firms. Panel 
A of Table 1 shows the details. ${ }^{2}$

Panel B of Table 1 describes the distribution of our sample firms based on their legal type, using CDS spread and default probability as measures of firm default risk respectively. The four sectors of financial firms are Banking, Financial Services, Insurance, and Real Estate, respectively. Specifically, in CDS-spread sample, banks account for more than half of the sample with 67 firms $(57.26 \%)$. Besides, the other three sectors respectively take over nearly the same percentage of financial firms in our sample (Financial Services: 14.53\%; Insurance: 12.82\%; Real Estate: $15.38 \%)$.

Before we proceed with regressions, we first employ a probit model regression (shown in Panel $\mathrm{C}$ of Table 1) to test the propensity of sample firms launching the CDS market, by incorporating other financial firms without traded CDS. According to the results given by Panel C, firms with lower insider holdings and profit, stronger board independence, larger board size, more assets, and higher leverage ratios are more apt to enter CDS market. In addition, if the CEO of a company is also the chairman of the board, this company would be more inclined to have traded CDS. However, these findings would not provide any evidence on judging whether or not our sample has any selection bias since the companies with traded CDS in our sample are all the financial firms outside of the North America we can find from "Markit". Furthermore, under the consideration that our CDS sample is purely constructed with financial firms having traded CDS, we employ the Heckman selection model to take care of the potential problem on selection bias. As shown in Panel D of Table $1^{3}$, the estimate of $\rho$ (_Rho), the correlation between unobserved determinants of propensity to enter CDS market and unobserved determinants of CDS spread, is insignificant, indicating that selection bias is not a problem in our research. Thus, we will continue our regressions using the initial sample we collect.

In addition, Table 2 describing the distribution of firms by country is also provided, using CDS-spread and default-probability samples respectively.

2 In the selection process, we do not impose other restrictions (e.g. control the firms' size) on the sample.

3 Due to the page layout, we did not post the complete Heckman regression result into our paper and this will be provided on request. 
[Insert Table $1 \&$ Table 2 here]

\subsection{Description of variables}

\subsubsection{Measurement of firms' default risk}

One of the measurements of firms' default risk in our research is average 5-year Credit Default Swap (CDS) spread on highly liquid 5-year maturity CDS contracts. In measuring firms' default risk, literature has used several kinds of variables. For example, z-score (Roy, 1952; Laeven and Levine, 2009), the standard deviation of stock returns (Demsetz, Saidenberg, and Strahan, 1997), credit ratings (Skaife, Collins, and LaFond, 2006; Liu and Jiraporn, 2010), cumulative default probabilities (Switzer and Wang, 2013), 5-year CDS spread (Switzer and Wang, 2013), etc. A CDS is a contract which provides insurance against the default of a particular company, thus CDS can be used to measure companies' default risk. The higher the CDS spread is, the higher the firm's default risk would be, and vice versa. In a CDS, there are two parties to the contract: the buyer of credit protection makes periodic payments to the seller of the credit protection until either the contract matures or there is a default event by the company. In exchange for the periodic payments made by the buyer, the seller agrees to pay the buyer the difference between the face value and the market value of the reference obligation if a credit event occurs. If no default event occurs, the protection buyer still makes all the agreed-upon payments. There is a payment to compensate for default losses only in the case of a default event (Markit Inc.). The above is the basic definition of CDS. As in any swap, the premium (which determines the annuity payments) is the rate that equates the expected streams of cash flows that the buyer and the seller make. The CDS premium (CDS spread) therefore contains information on the default probability associated with a reference entity, since this information is embedded in the expected payment made by the protection buyer. Furthermore, CDS is less, although not completely, sensitive to liquidity effects, since securities are in fixed supply, while the supply of CDS can be arbitrarily large. Therefore, due to lack of restriction on liquidity, CDS provides a better measure of default risk. The data 
source that we use is from Markit database, the leading provider of CDS data that have been employed in studies.

However, although CDS is a better measure of firm's default risk, only a few papers have used it in the research on exploring corporate governance and firm's default risk (see e.g. Switzer and Wang (2013) who look at US firms). Thus, one of the contribution of our paper is that we try to fill the gap in exploring the relationship between firms' default risk and corporate governance by the use of CDS spread as the measure of risk.

The alternative measure of firms' default risk is the 5-year default probability provided by Bloomberg database. According to Bloomberg, the regarding default likelihood model used to calculate the 5-year default probability is based on the Merton distance-to-default (DD) measure (Merton, 1974), along with additional economically and statistically relevant factors. The smaller the DD, the closer the firm is to default or higher default risk. The DD function is shown below (Bharath and Shumway, 2008):

$$
D D=\frac{\ln \left(\frac{V_{0}}{D}\right)+\left(\mu-\frac{\sigma^{2}}{2}\right) T}{\sigma \sqrt{T}}
$$

where $V_{0}$ is the total assets value of the firm at time $0 ; \sigma$ is the asset volatility; $\mu$ is the asset drift; $D$ is the debt liabilities of the firm; $T$ is the time to maturity; $D D$ is the distance to default. The key insight of the Merton framework is that the equity of the firm can be viewed as a call option on the total assets of the firm where the strike price is equal to its liabilities. However, the limitation in the original Merton framework is that it assumes that a firm can default only at the maturity of firms' liabilities, which are assumed to be zero coupon bonds. In reality, default can occur at any time. Instead, the Bloomberg default likelihood model overcomes this limitation by treating equity as a barrier call option to calculate the DD, explicitly incorporating the possibility that the firm defaults before the maturity of the debt (Bloomberg). Then Bloomberg use the improved DD as one of the key parameters in its model, plus a mapping between DD and actual 
default rates, to build a nonlinear function of DD over default probability, which is expressed as:

$$
\text { Default probability }=\mathrm{f}(\text { distance-to-default })
$$

Where $\mathrm{f}$ is a nonlinear function. Bharath and Shumway (2008) show that while DD is a significant predictor of default, it is not a sufficient statistic since the above paper successfully constructs a reduced-form model with better predictive properties from the Merton DD model. Thus, considering the comments from the above paper, Bloomberg improves its default probability model by including additional information regarding different sectors in different industries. In our research, we use the Bloomberg 5-year default probability as the second measure of firms' default risk to compare with CDS spread, under the consideration of the potential endogenous problem between institutional ownership and CDS spread.

\subsubsection{Measurements of corporate governance and firm characteristics}

Institutional ownership: We use institutional stock holdings (insti_holding) as the representative of institutional ownership, defined as the percentage of shares outstanding held by institutions.

Insider ownership: This variable (insid_holding) is defined as the percentage of outstanding shares currently held by corporate insiders.

Boards and CEO power: To describe board characteristics, we use board independence (board_indep), which is defined as the percentage of independent directors in total board membership and is one of the most extensively studied board characteristics (Weisbach, 1988), and board size (board_size) that is the number of directors on the company's board. In addition, we use CEO duality (ceo_duality), a dummy variable indicating whether a company's Chief Executive Officer is also the chairman of the Board, to measure how powerful the CEO is in the company.

In addition, based on previous literature, we control firm size (total_assets), return on assets (roa), leverage (ltd), and price-to-book ratio (pb) (e.g., Bhojraj and Sengupta, 2003; Skaife, Collins, and LaFond, 2006; Aebi, Sabato, and Schmid, 2012; Erkens, Hung, and Matos, 2012). The frequency of all the data is annual and the detailed definitions of variables and data sources are shown in Appendix A. 


\section{[Insert Table 3 here]}

Table 3 exhibits the Pearson correlation matrix. The biggest absolute value of coefficient of correlation between variables lies between board independence and CEO duality at - 0.4408 , which implies that the higher percentage of independent directors in the board, the less likely the CEO is to become the chairman of the board and thus avoid CEO power expansion. Besides, the second biggest coefficient estimate is the one of CDS spread and default probability, 0.4091. Apart from these coefficients, the other coefficients of significant correlations are generally small. Overall, there is no seriously high correlation between explanatory variables. Thus, in our research, we employ all these variables shown in Table 3 in our regressions.

\subsubsection{MSCI indexes}

The Morgan Stanley Capital International (MSCI) indexes are constructed and maintained by Morgan Stanley for more than 40 years to measure the macro performance over different markets. They can be used as benchmarks for stock funds and used widely in academic research. Gupta, Krishnamurti, and Tourani-Rad (2013) use MSCI-EAFE index (one of MSCI indexes) as the benchmark to measure the various development in different countries across their global firms' sample and study the impact of internal corporate governance on firm performance during current financial crisis. In our study, we choose the MSCI-country index. This index is constructed to measure the market performance of every country displayed in the MSCI country list.

\subsection{Mean of main variables by country}

We provide the mean of our main variables used in our research sorted by country, which gives us a brief description of those main variables in each country. As we notice in Table 4, Greece and Ireland have a slightly higher average 5-year CDS spread compared to other countries. Accordingly, we incorporate the country dummy (equals to 1 if it is Greece or Ireland and 0 otherwise) into the full sample regressions with dummies to test whether these two countries are 
the outliers. Furthermore, we also find that a Japanese firm in our sample has incredibly high CDS spread, due to the occurrence of its default issue. Accordingly, we include another dummy variable equals to one if it is the Japanese firm with the highest CDS spread. In the constituent of sample, firms from Europe and Asia take up the main percentage of our sample, 52 and 54 firms respectively. Thus, we compare the performance of firms from these two continents in our research by running separate regressions.

\section{[Insert Table 4 here]}

\section{Methodology and empirical results}

\subsection{Endogeneity tests}

Institutional holdings are considered to be a potential endogenous variable with respect to the CDS spread. We assume in our equation that institutional ownership can affect the CDS spread by playing the monitoring role in the company. However, the CDS spread may also affect the investment behavior of institutions. For example, if the performance of a firm is poor and its default risk rises, institutions may decrease the percentage of their holdings in the company. Thus, if we regress CDS spread on the institutional holdings in the same equation, endogeneity problem may occur. Accordingly, we introduce two instrumental variables to address the concern that high CDS spread may drive away the institutions. These variables are: (1) the membership in the MSCIcountry index; (2) the one-year lag of market-adjusted return on assets of the firm. The first instrument is a dummy variable equals to one if the firm is a member in the firm list of MSCIcountry index of the country and zero otherwise. The use of this instrument follows Aggarwal et al. (2011), which similarly use membership in the MSCI-world index as an instrumental variable for total and foreign institutional ownership. Ferreira and Matos (2008) find that the MSCI membership helps a firm attract foreign capital. Thus, MSCI-country index membership is correlated with our ownership measurement but not directly correlated to individual firm's default risk. The second instrument is one-year lag of a firm's adjusted return on assets, i.e. return on assets minus MSCI-country index, while MSCI-country index is used as a market benchmark to adjust. 
The employment of the second instrumental variable is inspired by Cornett et al. (2007), which include the lagged market-adjusted return of a firm (i.e., annual firm return minus the return on the S\&P 500 index). A positive market-adjusted return might encourage institutions to increase the investment to the company in the next year.

We proceed with endogeneity tests by running the test of over-identifying constraints using Generalized Method of Moments (GMM) estimation (results are shown in Appendix B). Considering the potential influence of default issue of that Japanese firm, we have two separate results of the same test, with or without the Japanese firm in our sample. According to the overidentifying tests, the J-statistics are insignificant with probability of 0.4758 and 0.2174 in two cases respectively, failing to reject the null hypothesis of the over-identifying constraints of the two instrumental variables and meaning that the instruments are valid. Then, we run the GMM endogeneity test to see whether those instrumental variables can help address the potential endogenous problem or, in other words, if there is any endogeneity problem between institutional holdings and CDS spread in our research (results are shown in Appendix B). From the results of GMM estimation, we find that the differences in J-statistics are completely insignificant, whether we exclude the Japanese firm of high CDS or not. ${ }^{4}$ That is to say, the endogeneity test cannot reject the null hypothesis of no endogeneity. Summarily, using these two instruments, the GMM overidentifying test and endogeneity test prove that there is no endogeneity concern between institutional ownership and CDS spread in our regressions and we will continue using the least squares method to conduct our regressions.

\subsection{Full sample regressions without constraints}

We first run regressions with the full sample without introducing any industry dummy variables, using the return on MSCI-country index (index_return) as the benchmark of every country. In order to compare the results, we use the average 5-year CDS spread (equation 1, 2, 3) and 5-year default probability (equation 4, 5,6) as the measures of a firm's default risk, respectively.

\footnotetext{
${ }^{4}$ The probabilities of difference are 0.4961 including the Japanese firm and 0.4737 excluding it
} 
The 6 equations in Table 4 report the regression results. All the regressions in our research have used time (year) fixed effect. Regressions with country fixed effect are also provided in Table 7 and Table 9. CDS spread and default probability are transformed as $\operatorname{Ln}[\mathrm{Y} /(1-\mathrm{Y})]$. Y represents CDS spread or Bloomberg default probability.

[Insert Table 5 here]

In the regressions of CDS spread in Table 5, the equation 1, 2, and 3, board size and institutional holdings of our corporate governance variables show significant relationship with the CDS spread. Comparing the equation 4, 5, and 6 using the default probability as the dependent variable, nearly all the measures of corporate governance and firms' fundamentals are significant at the $1 \%$ significance level. Specifically, higher institutional holdings, higher board independence and less insider holdings can lead to lower default probability. Furthermore, if a CEO is simultaneously the chairman of the board, the firm's default risk is higher. These findings are consistent with Brickley, Lease and Smith (1988) which find that institutions tend to object to firms' managerial decisions that are harmful to shareholders. Congruously, McConnell and Servaes (1990) find a positive relationship between firm value and institutional ownership. Regarding to the insider holdings, sometimes corporate insiders may find it personally beneficial to enhance firms' risk taking (Jensen and Meckling, 1976), implying a positive relationship between insider ownership and default probability. In addition, for board independence and CEO power, the findings on default probability follow Pathan (2009) and Skaife, Collins, and LaFond (2006), respectively. Even though currently those significant relationships are mostly found with firms' default probability and the results displayed on CDS-based regression are insignificant, we cannot claim no relationship between corporate governance and firms' default risk since (1) we have an international sample with many financial firms from different countries and many local characteristics may exist; (2) we have some "special" firms in our sample such as those firms from Greece and Ireland and the Japanese firm with the highest CDS during the three years. Thus, we 
will further control these two factors in the following regressions.

\subsection{Full sample regressions with dummies}

As firms from Greece and Ireland have average higher CDS spread than do firms from other countries in our sample, we include a dummy variable (_st_dummy) equals to one if a firm is from Greece or Ireland, zero otherwise. Besides, considering that there is a Japanese firm with the incredibly high CDS spread (due to the occurrence of its own default issue), we employ a second dummy variable equals to one if a firm is the Japanese firm with the highest CDS spread. The empirical results are shown in Table 6 where equation 1, 2, 3, and 4 (equation 4 and 8 delete the Japanese firm from the sample) are CDS spread based and the rest are default probability based.

\section{[Insert Table 6 \& Table 7 here]}

Different from the former regressions of CDS spread without dummies, insider holdings becomes significantly positive at 1\% significance level, as shown from equation 3 and 4 of Table 6. This finding indicates that insiders with a higher percentage of shareholding in the company prefer higher risk in order to maximize shareholders' interest (Saunders, Strock, and Travlos, 1990). Board size is positively related to CDS spread after including those two dummies. The coefficient

of board independence, which is inverse from the results in Section 4.2, is now significantly positive, indicating that more independent directors there are in the board, the higher a firm's CDS spread will be. This result is consistent with the "wealth transfer" theory of Erkens, Hung, and Matos (2012), which find that higher percentage of independent directors in the board is associated with worse stock returns during the crisis period. Comparing with the CDS spread based regressions, the significant relationships in default probability based regressions still hold after including the dummy variables. Differently, while board characteristics have a positive relationship with CDS spread, they have a negative relationship with firms' default probability, suggesting that the findings on the relationship between board characteristics and firms' default risk are mixed with the international sample. The results of board independence and board size found on default 
probability based regressions follow the conclusion of Switzer and Wang (2013) which find that board independence negatively affects firms' default risk. When taking the country fixed effect into consideration, the findings are similar (shown in Table 7).

4.4 The continental comparison

As we notice in Table 4, firms from European and Asian countries account for the largest percentage of the full sample, with 52 and 54 out of 117 firms respectively. Accordingly, we compare a sub-sample with only European firms and a sub-sample with only Asian firms in the regressions to test the different impacts of corporate governance between them.

\section{[Insert Table 8 \& Table 9 here]}

Panel A and Panel B in Table 8 shows the comparison between European firms and Asian firms, respectively. Surprisingly, in Panel A, no corporate governance variables are significantly related to CDS spread except board size. And many significant relationships between corporate governance and default probability now disappear in the regressions on European financial firms. Instead, in Panel B, CEO duality and board independence are still significantly and positively related to CDS spread. Moreover, the institutional holdings, insider holdings, and board characteristics still show significance in the regressions of default probability, but with different signs of coefficients from those in CDS based regressions. Based on the results of Table 6, we notice that results of board characteristics (inverse direction of coefficients) found in Asian firms are consistent with the findings in Table 6, while this inverse relationship between using CDS spread and default probability does not appear in European firms. When taking the country fixed effect into consideration, the findings are similar (shown in Table 9).

Considering all the results we find, we have to mention that the data availability is still a limitation to our research. For example, the data on financial firms with traded CDS only consists 117 financial firms comparing to data of default probability on 719 financial firms. 


\section{Conclusion}

In this research, we investigate the relationship between firm default risk and corporate governance in the post period of 2008 financial crisis, using CDS spread and default probability as two alternative measurements of firm default risk. Our research can contribute in three ways: first, unlike most literature which focuses on the impact of the crisis during the two serious years (20072008), we provide new evidence on the role of corporate governance during the post financial crisis period. Second, as much attention has been drawn on North American markets for the financial crisis, instead, we select our study sample from markets outside of North America in order to find out what was happening for those financial firms from 2010 to 2012; Third, we use two alternative gauges of default risk: CDS spreads and the Black-Scholes-Merton distance to default measure.

In the full-sample regressions without constraints, we find that institutional ownership has a weak negative relationship with CDS spread, meaning that institutions may have a monitoring effect on firms' risk control around the area outside of North America. After adding the two dummy variables into the regressions, insider holdings and board characteristics (board independence and board size) become positively related to CDS spread. Unlike the CDS spread, in the regressions with default probability, nearly all the corporate governance show significant relationship with firm default risk. When comparing the CDS spread with default probability, we find that: the negative relationship between institutional holdings and firm default risk holds, but it shows much stronger with default probability as the dependent variable, supporting the view that institutions have the monitoring effect in firm risk-taking; insider holdings is significantly related to CDS spread and default probability; board size always positively relates to CDS spread and default probability; board independence, however, is positively related to CDS spread and negatively associated with default probability, we find this inverse relationship in regressions with full sample and sub-sample with Asian firms. CEO duality has no significant association with CDS spread, except in subsample with Asian firms, but significantly related with default probability. Furthermore, when we split the full sample into European firms and Asian firms, those findings in the two sub-samples are different, implying a continental difference. In addition, since we have mixed evidence on board characteristics, apart from comparing the characteristics of CDS spread and default probability 
themselves, we should also try to enlarge the size of our sample in the future to avoid any concern due to the limit of data.

Therefore, future improvements for this research can focus on extending the research time period and expanding the sample size. However, based on our sample selection, the 117 financial firms which are traded on CDS markets and outside of North America are all we can find currently. 


\section{References}

Aebi, Vincent, Gabriele Sabato, and Markus Schmid. "Risk management, corporate governance, and bank performance in the financial crisis." Journal of Banking \& Finance 36, no. 12 (2012): 3213-3226.

Aggarwal, Reena, Isil Erel, Miguel Ferreira, and Pedro Matos. "Does governance travel around the world? Evidence from institutional investors."Journal of Financial Economics 100, no. 1 (2011): 154-181.

Anderson, Ronald C., and Donald R. Fraser. "Corporate control, bank risk taking, and the health of the banking industry." Journal of Banking \& Finance24, no. 8 (2000): 1383-1398.

Ashbaugh-Skaife, Hollis, Daniel W. Collins, and Ryan LaFond. "The effects of corporate governance on firms' credit ratings." Journal of accounting and economics 42, no. 1 (2006): 203243.

Beltratti, Andrea, and René M. Stulz. "The credit crisis around the globe: Why did some banks perform better?" Journal of Financial Economics 105, no. 1 (2012): 1-17.

Bharath, Sreedhar T., and Tyler Shumway. "Forecasting default with the Merton distance to default model." Review of Financial Studies 21, no. 3 (2008): 1339-1369.

Bhojraj, Sanjeev, and Partha Sengupta. "Effect of corporate governance on bond ratings and yields: The role of institutional investors and outside directors*." The Journal of Business 76, no. 3 (2003): 455-475.

Bloomberg L.P. " Bloomberg credit risk DRSK< go> framework, methodology and usage." (2015). Bloomberg database. John Molson School of Business, Concordia University. 20 July, 2015.

Brickley, James A., Ronald C. Lease, and Clifford W. Smith. "Ownership structure and voting on antitakeover amendments." Journal of financial economics 20 (1988): 267-291. 
Caprio, Gerard, Luc Laeven, and Ross Levine. "Governance and bank valuation." Journal of Financial Intermediation 16, no. 4 (2007): 584-617.

Cornett, Marcia Millon, Alan J. Marcus, Anthony Saunders, and Hassan Tehranian. "The impact of institutional ownership on corporate operating performance." Journal of Banking \& Finance 31, no. 6 (2007): 1771-1794.

Crutchley, Claire E., Marlin RH Jensen, John S. Jahera, and Jennie E. Raymond. "Agency problems and the simultaneity of financial decision making: The role of institutional ownership." International review of financial analysis 8, no. 2 (1999): 177-197.

Demsetz, Rebecca S., Marc R. Saidenberg, and Philip E. Strahan. "Agency problems and risk taking at banks." FRB of New York Staff Report 29 (1997).

Erkens, David H., Mingyi Hung, and Pedro Matos. "Corporate governance in the 2007-2008 financial crisis: Evidence from financial institutions worldwide."Journal of Corporate Finance 18, no. 2 (2012): 389-411.

Fahlenbrach, Rüdiger, and René M. Stulz. "Bank CEO incentives and the credit crisis." Journal of Financial Economics 99, no. 1 (2011): 11-26.

Ferreira, Miguel A., and Pedro Matos. "The colors of investors' money: The role of institutional investors around the world." Journal of Financial Economics 88, no. 3 (2008): 499-533.

Garcia, Alejandro, and Jun Yang. "Understanding corporate bond spreads using credit default swaps." Bank of Canada Review 2009, no. Autumn (2009): 27-35.

Gorton, Gary, and Richard Rosen. Corporate control, portfolio choice, and the decline of banking. No. w4247. National Bureau of Economic Research, 1992.

Gupta, Kartick, Chandrasekhar Krishnamurti, and Alireza Tourani-Rad. "Is corporate governance relevant during the financial crisis?." Journal of International Financial Markets, Institutions and Money 23 (2013): 85-110. 
Hall, Robert E. "Why does the economy fall to pieces after a financial crisis?" The Journal of Economic Perspectives (2010): 3-20.

Imhoff, Gene. "Accounting quality, auditing and corporate governance." Auditing and Corporate Governance (January 2003) (2003).

Jensen, Michael C., and William H. Meckling. "Theory of the firm: Managerial behavior, agency costs and ownership structure." Journal of financial economics 3, no. 4 (1976): 305-360.

Laeven, Luc, and Ross Levine. "Bank governance, regulation and risk taking."Journal of Financial Economics 93, no. 2 (2009): 259-275.

Li, Donghui, Fariborz Moshirian, Pascal Nguyen, and Li-Wen Tan. "Managerial ownership and firm performance: Evidence from China's privatizations."Research in International Business and Finance 21, no. 3 (2007): 396-413.

Liu, Chunyan, Konari Uchida, and Yufeng Yang. "Corporate governance and firm value during the global financial crisis: Evidence from China." International Review of Financial Analysis 21 (2012): 70-80.

Liu, Yixin, and Pornsit Jiraporn. "The effect of CEO power on bond ratings and yields." Journal of Empirical Finance 17, no. 4 (2010): 744-762.

McConnell, John J., and Henri Servaes. "Additional evidence on equity ownership and corporate value." Journal of Financial economics 27, no. 2 (1990): 595-612.

Merton, Robert C. "On the pricing of corporate debt: The risk structure of interest rates*." The Journal of Finance 29, no. 2 (1974): 449-470.

Pathan, Shams. "Strong boards, CEO power and bank risk-taking." Journal of Banking \& Finance 33, no. 7 (2009): 1340-1350. 
Podder, Jyotirmoy, Michael T. Skully, and Kym Brown. "Independent directors and risk taking: Evidence from listed US insurance companies." Systemic Risk: Liquidity Risk, Governance and Financial Stability (2013).

Roy, Andrew Donald. "Safety first and the holding of assets." Econometrica: Journal of the Econometric Society (1952): 431-449.

Ryan, Stephen G. "Accounting in and for the subprime crisis." The accounting review 83, no. 6 (2008): 1605-1638.

Saunders, Anthony, Elizabeth Strock, and Nickolaos G. Travlos. "Ownership structure, deregulation, and bank risk taking." the Journal of Finance 45, no. 2 (1990): 643-654.

Switzer, Lorne N., and Jun Wang. "Default risk estimation, bank credit risk, and corporate governance." Financial Markets, Institutions \& Instruments 22, no. 2 (2013): 91-112.

Switzer, Lorne N., and Jun Wang. "Default risk and corporate governance in financial vs. nonfinancial firms." Risk and Decision Analysis 4, no. 4 (2013): 243-253.

Weisbach, Michael S. "Outside directors and CEO turnover." Journal of financial Economics 20 (1988): 431-460. 
Table 1: Sample description

Panel A: Sample selection

No. of firms dropped

10993

2

28

Financial firms without data on corporate goverance and fundamentals

Remainning firms

Bloomberg financial firms (- North America)

11140

Less

Financial firms without traded CDS

Financial firms without data on CDS spread

Final sample

Panel B: Sector distribution of the final sample

\begin{tabular}{|c|c|c|c|c|}
\hline \multirow{2}{*}{ Industry } & \multicolumn{2}{|c|}{ Default-probability sample } & \multicolumn{2}{|c|}{ CDS-spread sample } \\
\hline & No. & $\%$ & No. & $\%$ \\
\hline Banking & 221 & $30.74 \%$ & 67 & $57.26 \%$ \\
\hline Financial services & 190 & $26.43 \%$ & 17 & $14.53 \%$ \\
\hline Insurance & 67 & $9.32 \%$ & 15 & $12.82 \%$ \\
\hline Real estate & 241 & $33.52 \%$ & 18 & $15.38 \%$ \\
\hline Total & 719 & $100 \%$ & 117 & $100 \%$ \\
\hline
\end{tabular}

Panel C: Probit model

Number of observations used: 1942

\begin{tabular}{ccclll}
\hline Parameter & DF & Estimate & $\begin{array}{l}\text { Standard } \\
\text { Error }\end{array}$ & $\begin{array}{l}\text { Wald } \\
\text { Chi-Square }\end{array}$ & Pr $>$ ChiSq \\
\hline insti_holding & 1 & 0.0528 & 0.1249 & 0.1787 & 0.6725 \\
insid_holding & 1 & -4.6448 & 1.2229 & 14.4260 & $\mathbf{0 . 0 0 0 1}$ \\
board_indep & 1 & 1.0429 & 0.1631 & 40.9013 & $<.0001$ \\
board_size & 1 & 1.1760 & 0.1277 & 84.8257 & $<.0001$ \\
ceo_duality & 1 & 0.3552 & 0.0979 & 13.1674 & $\mathbf{0 . 0 0 0 3}$ \\
total_assets & 1 & 0.0006 & 0.0001 & 30.4504 & $<.0001$ \\
roa & 1 & -2.0428 & 0.8999 & 5.1532 & $\mathbf{0 . 0 2 3 2}$ \\
ltd & 1 & 0.9855 & 0.2376 & 17.2035 & $\mathbf{< 0 0 0 1}$ \\
pb & 1 & -0.1532 & 0.0465 & 10.8408 & $\mathbf{0 . 0 0 1}$
\end{tabular}

Panel D: Heckman correction

Parameter estimates

\begin{tabular}{cccccc}
\hline Parameter & DF & Estimate & Standard Error & $\mathrm{t}$ Value & Approx $\operatorname{Pr}>|\mathrm{t}|$ \\
Rho & 1 & -0.189567 & 0.126041 & -1.5 & 0.1326 \\
\hline
\end{tabular}

Rho: the correlation between unobserved determinants of propensity to enter CDS market and unobserved determinants of CDS spread. 
Table 2: Distribatien of Fines by Cemetry

\begin{tabular}{|c|c|c|c|c|c|c|c|}
\hline \multicolumn{4}{|c|}{ Pand A-CDS-spread sample } & \multicolumn{4}{|c|}{ Pand B: Defanlt-probability sample } \\
\hline Conitry & Number & $\begin{array}{l}\text { Percentage in the sub- } \\
\text { sample of continent }\end{array}$ & $\begin{array}{l}\text { Pecentage in the } \\
\text { complete sample }\end{array}$ & Country & Number & $\begin{array}{c}\text { Percentage in the sub- } \\
\text { sample of cortinent }\end{array}$ & $\begin{array}{l}\text { Percentage in the } \\
\text { complete sample }\end{array}$ \\
\hline Anstrylasia & & & & Anstralasia & & & \\
\hline Australia & 9 & $100 \%$ & $7.69 \%$ & Australia & 52 & $100 \%$ & $723 \%$ \\
\hline Prrepe & & & & Eurcpe & & & \\
\hline Anstria & 1 & $192 \%$ & $0.85 \%$ & Anstria & 5 & $254 \%$ & $0.70 \%$ \\
\hline Belgium & $\mathbf{1}$ & $192 \%$ & $0.85 \%$ & Bedgium & 9 & $457 \%$ & $125 \%$ \\
\hline Denmark & $\mathbf{1}$ & $192 \%$ & $0.85 \%$ & Denmark & 3 & $152 \%$ & $0.42 \%$ \\
\hline Finland & $\mathbf{1}$ & $192 \%$ & $0.85 \%$ & Finland & 6 & $3.05 \%$ & $083 \%$ \\
\hline France & 10 & $1923 \%$ & $\mathbf{8 5 5} \%$ & France & 17 & $8.63 \%$ & $236 \%$ \\
\hline Gemany & 2 & $3.85 \%$ & $1.71 \%$ & Gemany & 4 & $2.03 \%$ & $056 \%$ \\
\hline Greece & 3 & $5.77 \%$ & $256 \%$ & Greece & 5 & $254 \%$ & $0.70 \%$ \\
\hline Ireland & 1 & $192 \%$ & $0.85 \%$ & Irdand & 5 & $254 \%$ & $0.70 \%$ \\
\hline Italy & 4 & $7.69 \%$ & $3.42 \%$ & Italy & 16 & 8.12\% & $223 \%$ \\
\hline Netherands & 1 & $192 \%$ & $0.85 \%$ & Netherlands & 4 & $2.03 \%$ & $056 \%$ \\
\hline Norway & 1 & $192 \%$ & $0.85 \%$ & Norway & 7 & $355 \%$ & $097 \%$ \\
\hline Portugral & 2 & $3.85 \%$ & $1.71 \%$ & Patugil & 3 & $152 \%$ & $0.42 \%$ \\
\hline Spain & 4 & $7.69 \%$ & $3.42 \%$ & Spain & 9 & $457 \%$ & $125 \%$ \\
\hline Sweden & 3 & $5.77 \%$ & $256 \%$ & Sweden & 18 & $9.14 \%$ & $250 \%$ \\
\hline Switzedand & 4 & $7.69 \%$ & $3.42 \%$ & Switzerland & 12 & $6.09 \%$ & $167 \%$ \\
\hline Turkey & 1 & $192 \%$ & $0.85 \%$ & Turkey & 12 & $6.09 \%$ & $1.67 \%$ \\
\hline United Kingdom & 12 & $23.08 \%$ & $1026 \%$ & United Kingdnm & 62 & $31.47 \%$ & $8.62 \%$ \\
\hline Asin & & & & Asia & & & \\
\hline Ohina & 4 & $7.41 \%$ & $3.42 \%$ & China & 112 & $24.78 \%$ & $1558 \%$ \\
\hline Hongkmg & 8 & $1481 \%$ & $6.84 \%$ & Hongkong & 36 & $796 \%$ & $5.01 \%$ \\
\hline India & 7 & $1296 \%$ & $598 \%$ & India & 86 & $19.03 \%$ & $1196 \%$ \\
\hline Israel & $\mathbf{1}$ & $185 \%$ & $0.85 \%$ & Israd & 5 & $1.11 \%$ & $0.70 \%$ \\
\hline Japan & 25 & $4630 \%$ & $2137 \%$ & Japan & 165 & $3650 \%$ & $2295 \%$ \\
\hline Malaysia & 2 & $3.70 \%$ & $1.71 \%$ & Malaysia & 16 & $354 \%$ & $223 \%$ \\
\hline Singepore & 3 & $556 \%$ & $256 \%$ & Singrpore & 21 & $4.65 \%$ & $292 \%$ \\
\hline Thailand & 4 & $7.41 \%$ & $3.42 \%$ & Thailand & 11 & $2.43 \%$ & $153 \%$ \\
\hline \multicolumn{4}{|c|}{ Seath Aberica ad athers } & \multicolumn{4}{|c|}{ South America and others } \\
\hline Brazil & $\mathbf{1}$ & $50 \%$ & $0.85 \%$ & Brazil & 15 & $8333 \%$ & $2.09 \%$ \\
\hline Ohile & 1 & $50 \%$ & $0.85 \%$ & Chile & 3 & $16.67 \%$ & $0.42 \%$ \\
\hline
\end{tabular}


Table 3: Pearson Correbtion Test

Prob $>|r|$ underH0: Rho $=0$

\begin{tabular}{|c|c|c|c|c|c|c|c|c|c|c|c|}
\hline & acds_trans & 中_trans & insti_holding & insid_holling & ceo_duality & board_indep & boand_size & total_assets & roa & lit & pb \\
\hline acds_trans & 1 & $\begin{array}{c}0.4091 \\
(<.0001)\end{array}$ & $\begin{array}{r}-0.1258 \\
(0.0234)\end{array}$ & $\begin{array}{c}0.0872 \\
(0.1165)\end{array}$ & $\begin{array}{c}0.0669 \\
(0.2291)\end{array}$ & $\begin{array}{r}-0.0354 \\
(0.5254)\end{array}$ & $\begin{array}{c}0.0834 \\
(0.1337)\end{array}$ & $\begin{array}{r}-0.0237 \\
(0.6705)\end{array}$ & $\begin{array}{c}-0.2634 \\
(<.0001)\end{array}$ & $\begin{array}{l}0.0931 \\
(0.094)\end{array}$ & $\begin{array}{r}-0.2119 \\
(0.0001)\end{array}$ \\
\hline 中_trans & $\begin{array}{c}0.4091 \\
(<-0001)\end{array}$ & 1 & $\begin{array}{c}-0.1370 \\
(<.0001)\end{array}$ & $\begin{array}{c}0.0313 \\
(0.1686)\end{array}$ & $\begin{array}{c}0.1755 \\
(<.0001)\end{array}$ & $\begin{array}{c}-0.1840 \\
(<-0001)\end{array}$ & $\begin{array}{c}0.0576 \\
(0.0111)\end{array}$ & $\begin{array}{c}0.0485 \\
(0.0325)\end{array}$ & $\begin{array}{c}-03160 \\
(<0001)\end{array}$ & $\begin{array}{c}0.1675 \\
(<0001)\end{array}$ & $\begin{array}{c}-0.2331 \\
(<0001)\end{array}$ \\
\hline insti_holding & $\begin{array}{c}-0.1258 \\
(0.0234)\end{array}$ & $\begin{array}{l}-0.1370 \\
(<.0001)\end{array}$ & $\mathbf{1}$ & $\begin{array}{l}-0.2006 \\
(<.0001)\end{array}$ & $\begin{array}{l}-0.1507 \\
(<.0001)\end{array}$ & $\begin{array}{c}0.1245 \\
(<.0001)\end{array}$ & $\begin{array}{c}0.1481 \\
(<0001)\end{array}$ & $\begin{array}{c}0.1108 \\
(<0001)\end{array}$ & $\begin{array}{r}-0.0098 \\
(0.6664)\end{array}$ & $\begin{array}{c}0.0729 \\
(0.0013)\end{array}$ & $\begin{array}{r}-0.0728 \\
(0.0013)\end{array}$ \\
\hline insid_holfing & $\begin{array}{c}0.0872 \\
(0.1165)\end{array}$ & $\begin{array}{c}0.0313 \\
(0.1686)\end{array}$ & $\begin{array}{l}-0.2006 \\
(<0001)\end{array}$ & $\mathbf{1}$ & $\begin{array}{c}0.1208 \\
(<.0001)\end{array}$ & $\begin{array}{r}-0.0078 \\
(0.7308)\end{array}$ & $\begin{array}{c}-0.2092 \\
(<0001)\end{array}$ & $\begin{array}{l}-0.1104 \\
(<0001)\end{array}$ & $\begin{array}{c}0.2560 \\
(<.0001)\end{array}$ & $\begin{array}{c}0.0292 \\
(0.1987)\end{array}$ & $\begin{array}{c}0.0824 \\
(0.0003)\end{array}$ \\
\hline ceo_duality & $\begin{array}{c}0.0669 \\
(0.2291)\end{array}$ & $\begin{array}{c}0.1755 \\
(<0001)\end{array}$ & $\begin{array}{l}-0.1507 \\
(<0001)\end{array}$ & $\begin{array}{c}0.1208 \\
(<-0001)\end{array}$ & $\mathbf{1}$ & $\begin{array}{c}-0.4408 \\
(<0001)\end{array}$ & $\begin{array}{c}-0.1719 \\
(<0001)\end{array}$ & $\begin{array}{c}-0.0996 \\
(<0001)\end{array}$ & $\begin{array}{r}-0.0725 \\
(0.0014)\end{array}$ & $\begin{array}{c}-0.1049 \\
(<0001)\end{array}$ & $\begin{array}{r}-0.0503 \\
(0.0267)\end{array}$ \\
\hline board_indep & $\begin{array}{r}-0.0354 \\
(0.5254)\end{array}$ & $\begin{array}{c}-0.1840 \\
(<0001)\end{array}$ & $\begin{array}{c}0.1245 \\
(<.0001)\end{array}$ & $\begin{array}{r}-0.0078 \\
(0.7308)\end{array}$ & $\begin{array}{c}-0.4408 \\
(<-0001)\end{array}$ & $\mathbf{1}$ & $\begin{array}{c}0.0009 \\
(0.9674)\end{array}$ & $\begin{array}{c}0.1243 \\
(<0001)\end{array}$ & $\begin{array}{c}0.0792 \\
(0.0005)\end{array}$ & $\begin{array}{c}0.1604 \\
(<.0001)\end{array}$ & $\begin{array}{c}0.0887 \\
(<0001)\end{array}$ \\
\hline boand_size & $\begin{array}{c}0.0834 \\
(0.1337)\end{array}$ & $\begin{array}{c}0.0576 \\
(0.0111)\end{array}$ & $\begin{array}{c}0.1481 \\
(<-0001)\end{array}$ & $\begin{array}{c}-0.2092 \\
(<.0001)\end{array}$ & $\begin{array}{c}-0.1719 \\
(<-0001)\end{array}$ & $\begin{array}{c}0.0009 \\
(0.9674)\end{array}$ & $\mathbf{1}$ & $\begin{array}{c}03174 \\
(<0001)\end{array}$ & $\begin{array}{c}-0.1718 \\
(<0001)\end{array}$ & $\begin{array}{r}-0.0766 \\
(0.0007)\end{array}$ & $\begin{array}{r}-0.1256 \\
(<0001)\end{array}$ \\
\hline total_assets & $\begin{array}{r}-0.0237 \\
(0.6705)\end{array}$ & $\begin{array}{c}0.0485 \\
(0.0325)\end{array}$ & $\begin{array}{c}0.1108 \\
(<-0001)\end{array}$ & $\begin{array}{c}-0.1104 \\
(<-0001)\end{array}$ & $\begin{array}{c}-0.0996 \\
(<-0001)\end{array}$ & $\begin{array}{c}0.1243 \\
(<-0001)\end{array}$ & $\begin{array}{c}03174 \\
(<-0001)\end{array}$ & $\mathbf{1}$ & $\begin{array}{c}-0.1331 \\
(<.0001)\end{array}$ & $\begin{array}{r}-0.0748 \\
(0.001)\end{array}$ & $\begin{array}{r}-0.0723 \\
(0.0014)\end{array}$ \\
\hline roa & $\begin{array}{c}-0.2634 \\
(<-0001)\end{array}$ & $\begin{array}{c}-0.3160 \\
(<0001)\end{array}$ & $\begin{array}{r}-0.0098 \\
(0.6664)\end{array}$ & $\begin{array}{c}0.2560 \\
(<-0001)\end{array}$ & $\begin{array}{r}-0.0725 \\
(0.0014)\end{array}$ & $\begin{array}{c}0.0792 \\
(0.0005)\end{array}$ & $\begin{array}{c}-0.1718 \\
(<-0001)\end{array}$ & $\begin{array}{c}-0.1331 \\
(<0001)\end{array}$ & 1 & $\begin{array}{r}-0.0397 \\
(0.0804)\end{array}$ & $\begin{array}{c}0.2543 \\
(<.0001)\end{array}$ \\
\hline ltd & $\begin{array}{l}0.0931 \\
(0.094)\end{array}$ & $\begin{array}{c}0.1675 \\
(<.0001)\end{array}$ & $\begin{array}{c}0.0729 \\
(0.0013)\end{array}$ & $\begin{array}{c}0.0292 \\
(0.1987)\end{array}$ & $\begin{array}{l}-0.1049 \\
(<.0001)\end{array}$ & $\begin{array}{c}0.1604 \\
(<.0001)\end{array}$ & $\begin{array}{r}-0.0766 \\
(0.0007)\end{array}$ & $\begin{array}{l}-0.0748 \\
(0.001)\end{array}$ & $\begin{array}{r}-0.0397 \\
(0.0804)\end{array}$ & $\mathbf{1}$ & $\begin{array}{l}-0.0458 \\
(0.0437)\end{array}$ \\
\hline pb & $\begin{array}{r}-0.2119 \\
(0.0001)\end{array}$ & $\begin{array}{c}-0.2331 \\
(<0001)\end{array}$ & $\begin{array}{r}-0.0728 \\
(0.0013)\end{array}$ & $\begin{array}{c}0.0824 \\
(0.0003)\end{array}$ & $\begin{array}{c}-0.0503 \\
(0.0267)\end{array}$ & $\begin{array}{c}0.0887 \\
(<\ldots 001)\end{array}$ & $\begin{array}{c}-0.1256 \\
(<0001)\end{array}$ & $\begin{array}{c}-0.0723 \\
(0.0014)\end{array}$ & $\begin{array}{c}0.2543 \\
(<0001)\end{array}$ & $\begin{array}{r}-0.0458 \\
(0.0437)\end{array}$ & $\mathbf{1}$ \\
\hline
\end{tabular}


Table 4: Mean of Mhin Variables by Ceantry

\begin{tabular}{|c|c|c|c|c|c|c|c|c|c|c|c|}
\hline & $\begin{array}{c}\text { Number of } \\
\text { firms }\end{array}$ & $\begin{array}{c}\text { Average CDS } \\
\text { spread (5yr) }\end{array}$ & $\begin{array}{l}\text { Total assets } \\
\text { (\$B) }\end{array}$ & $\begin{array}{l}\text { Institutional } \\
\text { holdings }\end{array}$ & $\begin{array}{l}\text { Insider } \\
\text { holdings }\end{array}$ & $\begin{array}{c}\text { Board } \\
\text { independence }\end{array}$ & Board size & CEO duality & ROA & LTD & PB \\
\hline \multicolumn{12}{|l|}{ Anstralasia } \\
\hline Australia & 9 & 0.0194 & 673288 & 0.2030 & 0.0016 & 0.8788 & 22381 & $\mathbf{0}$ & 0.0130 & 0.1332 & 13803 \\
\hline \multicolumn{12}{|l|}{ Enrope } \\
\hline Austria & $\mathbf{1}$ & 0.0272 & 113.0960 & 03220 & 0.0008 & 0.7745 & 2.8476 & $\mathbf{0}$ & 0.0010 & 0.1678 & 0.6971 \\
\hline Belgium & 1 & 0.0168 & 1732403 & 02969 & 0.0043 & 0.7515 & 23661 & $\mathbf{0}$ & 0.0014 & $0 \_0542$ & $0 \_4758$ \\
\hline Denmark & 1 & 0.0225 & 205_1022 & 0.1131 & 0.0002 & 0.6069 & 2.6126 & o & 0.0010 & 03067 & 0.7223 \\
\hline Finland & $\mathbf{1}$ & 0.0247 & 13_1038 & 0.4362 & 0.0228 & 0.7546 & 2.1187 & $\mathbf{0}$ & 0.0397 & 0.0550 & 12761 \\
\hline France & 10 & 0.0245 & $575 \_1626$ & 0.4229 & 0.0217 & 05394 & 2.6049 & 03214 & 0.0192 & 03137 & 09001 \\
\hline Germany & 2 & 0.0112 & 318.7935 & 0.4157 & $\mathbf{0}$ & 0.6042 & 2.7890 & o & 0.0047 & 0.0146 & 2_4402 \\
\hline Greece & 3 & 0.1427 & 76.4945 & 0.0914 & 0.0002 & 03457 & 2.7259 & $\mathbf{0}$ & -0.0438 & 0.0375 & 03859 \\
\hline Ireland & 1 & e.17es & 935951 & 09646 & 0.0009 & 0.6778 & 22499 & o & -0.0402 & 0.1322 & 13036 \\
\hline Italy & 4 & 0.0332 & 294_1465 & 03629 & $\mathbf{0}$ & 0.8592 & 3_0038 & 0.1 & -0.0008 & 02720 & 0.4544 \\
\hline Nethedands & 1 & 0.0234 & 168.4811 & 0.2856 & 0.0002 & 0.8956 & 22641 & o & 0.0042 & 0.0292 & $0 \_4213$ \\
\hline Norway & 1 & 0.0160 & 91.6258 & 0.7847 & 0.0011 & 0.6889 & 22675 & o & 0.0027 & 0.0183 & 0.8114 \\
\hline Partugil & 2 & 0.0745 & 969141 & 0.6243 & 0.0045 & 0.4839 & 32024 & o & 0.0016 & 02025 & $0 \_6838$ \\
\hline Spain & 4 & 0.0523 & 378.7362 & 03228 & 0.0232 & 05809 & 2.7189 & 02727 & 0.0017 & 02130 & 0.6816 \\
\hline Sweden & 3 & 0.0143 & 1132552 & 0.4275 & 0.0017 & 05685 & 244646 & $\mathbf{0}$ & 0.0054 & 03919 & 1.1760 \\
\hline Switzedand & 4 & 0.0140 & 3053738 & 0.5793 & 0.0024 & 09231 & 25522 & 0.2727 & 0.0120 & 0.1047 & 09377 \\
\hline Turkey & 1 & 0.0308 & 425533 & 0.7099 & o & 03111 & 2.2675 & o & 0.0221 & 0.0451 & 1.6028 \\
\hline United Kinglom & 12 & 0.0182 & 185.6167 & 09213 & 0.0029 & 0.6390 & 2.4943 & $\mathbf{0}$ & 0.0132 & 0.1310 & 1.1046 \\
\hline \multicolumn{12}{|l|}{ Asia } \\
\hline China & 4 & 0.0187 & 1243566 & 0.7413 & $\mathbf{0}$ & 03619 & 2.7257 & o & 0.0121 & 0.0465 & 12970 \\
\hline Hong Kong & 8 & 0.0158 & 30.6576 & 0.4122 & 0.0142 & 0.4033 & 2.6740 & 05 & 0.0653 & 0.1059 & 1.0364 \\
\hline Inda & 7 & 0.0269 & 14.7671 & 0.6923 & 0.0010 & 0.4701 & 2.4382 & 05 & 0.0170 & 02836 & 19485 \\
\hline Israel & $\mathbf{1}$ & 0.0250 & 612280 & 0.2911 & 0.0003 & 0.4570 & 2.7296 & $\mathbf{0}$ & 0.0074 & 0.0911 & 0.8452 \\
\hline Japan & 25 & 0.0390 & $80 \_1099$ & 0.4597 & 0.0059 & 0.1611 & 2.2912 & 0.6081 & 0.0044 & $0 \_1888$ & 0.7409 \\
\hline Malay sia & 2 & 0.0130 & 355157 & 03735 & 0.0067 & 0.6306 & 2.2924 & $\mathbf{0}$ & 0.0137 & $0 \_0478$ & 2.7016 \\
\hline Singrpore & 3 & 0.0169 & 43.8991 & 0.2927 & 0.0059 & 0.7505 & 2.4048 & $\mathbf{0}$ & 0.0556 & 0.1913 & 1.1108 \\
\hline Thailand & 4 & 0.0192 & 34.6003 & 05410 & 0.0017 & 0.4192 & 2.6314 & $\mathbf{0}$ & 0.0123 & 0.0797 & 1.6441 \\
\hline \multicolumn{12}{|c|}{ Senth Anerica and athers } \\
\hline Brazil & 1 & 0.0166 & 35.6625 & 05438 & $\mathbf{0}$ & 03572 & 19459 & $\mathbf{0}$ & 0.0147 & 0.1221 & 13703 \\
\hline Chile & $\mathbf{1}$ & 0.0208 & $30 \_0073$ & 09758 & 0.00002 & 0.7273 & 23979 & $\mathbf{0}$ & 0.0186 & 02691 & 35227 \\
\hline
\end{tabular}


Table 5: Full-sonple regresions

Table 5 shows the regressions on the full sample from 2010 to 2012, which neports the results from OIS negressions of CDS spread (equation 1, 2, and 3) and Defanlt probability (equation 4, 5, and 6) on a set of firms' coporate gowemance variables and control variables.CDS spread and Definlt probability are measured as the Ln [Y/(1-Y)] in the estimations, respectively_. insti holfing is the peroentage of shares outstanding held by institutions in the firm insid holding is pencentage of outstanding shares armently held by insiders. ceo duality is a drmmy indicating whether the conpany's Chief

Exeautive Officer is also Chaimen of the Boand, as neported by the company_ boand indep shows independent dinectors as a peroentape of total board membership. boand size is the log of number of

dinectors on the company's board, as reported by the company. index return, calculated by MSCI country index, is used to measure the merket performance of the reganding comtry. total assets is the log of total of all short and longtem assets as nepoted on the Balance Sheet of the firm roa is indicating of how profitable a company is netative to its total assets, in peroentage ltd measures the percentage of long term debt to total assets. pb is the ratio of the stock price to the book value per share ***, **, * denote statisticel significanoe at the $1 \%$, $5 \%$, and $10 \%$ levels, respectively. $t$ values ane reported in panentheses.

\begin{tabular}{|c|c|c|c|c|c|c|}
\hline & (1) & (2) & (3) & (4) & (5) & (6) \\
\hline Number of observations: & 325 & 325 & 325 & 1942 & 1942 & 1942 \\
\hline Intercept & $\begin{array}{r}-3.6434 \\
(-3731)\end{array}$ & $\begin{array}{c}-4.2805 \\
(-1142)\end{array}$ & $\begin{array}{l}-4.2918 \\
(-1128)\end{array}$ & $\begin{array}{c}-39274 \\
(-14866)\end{array}$ & $\begin{array}{l}-4.2749 \\
(-34.71)\end{array}$ & $\begin{array}{r}-39604 \\
(-33.19)\end{array}$ \\
\hline insti_holfing & & $\begin{array}{c}-03318^{* *} \\
(-2.04)\end{array}$ & $\begin{array}{c}-0.2552^{*} \\
(-165)\end{array}$ & & $\begin{array}{c}-0.2875^{* * *} \\
(-5.1)\end{array}$ & $\begin{array}{c}-0301^{* * *} \\
(-5.86)\end{array}$ \\
\hline insid_holfing & & $\begin{array}{l}1.8485 \\
(0.81)\end{array}$ & $\begin{array}{l}22063 \\
(1.02)\end{array}$ & & $\begin{array}{l}0.0712 \\
(056)\end{array}$ & $\begin{array}{c}0.4463^{* * *} \\
\text { (3.78) }\end{array}$ \\
\hline ceo_duality & & $\begin{array}{c}0.0992 \\
(0.86)\end{array}$ & $\begin{array}{l}0.0487 \\
(0.44)\end{array}$ & & $\begin{array}{c}02107 * * * \\
(4.88)\end{array}$ & $\begin{array}{c}0.1609 * * * \\
(4.09)\end{array}$ \\
\hline boand_indep & & $\begin{array}{l}-0.0637 \\
(-0.36)\end{array}$ & $\begin{array}{c}0.0968 \\
(0.58)\end{array}$ & & $\begin{array}{c}-03436 * * * \\
(-4.68)\end{array}$ & $\begin{array}{c}-03643^{* * *} \\
(-5.39)\end{array}$ \\
\hline boand_size & & $\begin{array}{l}0.235 * \\
(166)\end{array}$ & $\begin{array}{c}02807 * \\
(196)\end{array}$ & & $\begin{array}{c}0.211^{* * *} \\
(431)\end{array}$ & $\begin{array}{c}0.0875^{*} \\
(1.86)\end{array}$ \\
\hline index_netum & $\begin{array}{c}-0.5467^{* *} \\
(-241)\end{array}$ & & $\begin{array}{c}-0.4434^{*} \\
(-193)\end{array}$ & $\begin{array}{c}-0.7154^{* * *} \\
(-8.41)\end{array}$ & & $\begin{array}{c}-0.6388 * * * \\
(-7.77)\end{array}$ \\
\hline total_assets & $\begin{array}{l}-0.0001 \\
(-124)\end{array}$ & & $\begin{array}{r}-0.0001 \\
(-164)\end{array}$ & $\begin{array}{c}0.00002 \\
(051)\end{array}$ & & $\begin{array}{c}0.0001^{* *} \\
(232)\end{array}$ \\
\hline roa & $\begin{array}{c}-6.0277^{* * *} \\
(-4.6)\end{array}$ & & $\begin{array}{c}-6.4599^{* * * *} \\
(-493)\end{array}$ & $\begin{array}{c}-3.3959 * * * \\
(-1179)\end{array}$ & & $\begin{array}{c}-33313^{* * *} \\
(-1152)\end{array}$ \\
\hline ltd & $\begin{array}{c}0.5504^{* *} \\
(205)\end{array}$ & & $\begin{array}{c}0.6189 * * \\
(2.29)\end{array}$ & $\begin{array}{c}0.72^{* * *} \\
(7.14)\end{array}$ & & $\begin{array}{c}09287^{* * *} \\
(934)\end{array}$ \\
\hline pb & $\begin{array}{c}-0.1737 * * * \\
(-278)\end{array}$ & & $\begin{array}{c}-0.167^{* *} \\
(-253)\end{array}$ & $\begin{array}{c}-0.0444 * * * \\
(-72)\end{array}$ & & $\begin{array}{c}-0.0421^{* * *} \\
(-7,02)\end{array}$ \\
\hline Year fixed effect & Yes & Yes & Yes & Yes & Yes & Yes \\
\hline R-Square & $13.78 \%$ & $3.07 \%$ & $1635 \%$ & $17.73 \%$ & $6.48 \%$ & $2397 \%$ \\
\hline
\end{tabular}


Table 6: Full-sanple Regressions with Dunnies

T able 6 shows the regressions on the full sample from 2010 to 2012, which reports the ressults from OIS regressions of CDS spread (equation 1, 2, 3 and 4) and Defanlt probability (equation 5, 6 , 7 and 8) on a set of firms' corporate govemance variables and control variables. CDS spread and Default probability are measured as Ln[Y / (1-Y)] in the estimations, respectively.Different from $T$ able 4, it inserts two dummy variables. st dummy equals to 1 if a firm is from Greece or Iretand, 0 otherwise nd dummy equals to 1 if it is the Japanese firm with defanlt issue, 0 otherwise. $T$ he measures of other variables are the same as those shown in Table 4 - ***, **, * denote statistical significance at the $1 \%$, $5 \%$, and $10 \%$ kvets, respectively $t \mathrm{t}$ values are reported in parentheses.

\begin{tabular}{|c|c|c|c|c|c|c|c|c|}
\hline & (1) & (2) & (3) & (4) & (5) & (6) & (7) & (8) \\
\hline Number of observations: & 325 & 325 & 325 & 322 & 1942 & 1942 & 1942 & 1939 \\
\hline Intercept & $\begin{array}{l}-3.8412 \\
(-50.92)\end{array}$ & $\begin{array}{r}-4.2805 \\
(-11-42)\end{array}$ & $\begin{array}{c}-5.087 \\
(-18.28)\end{array}$ & $\begin{array}{l}-5.2027 \\
(-19.84)\end{array}$ & $\begin{array}{c}-39468 \\
(-148.04)\end{array}$ & $\begin{array}{r}-4.2749 \\
(-34.71)\end{array}$ & $\begin{array}{l}-39454 \\
(-3329)\end{array}$ & $\begin{array}{l}-3.9469 \\
(-33.28)\end{array}$ \\
\hline insti_holding & & $\begin{array}{c}-03318 * * \\
(-2.04)\end{array}$ & $\begin{array}{l}0.0817 \\
(0.72)\end{array}$ & $\begin{array}{l}0.078 \\
(0.73)\end{array}$ & & $\begin{array}{c}-0.2875 * * * * \\
(-5.1)\end{array}$ & $\begin{array}{c}-0.3127^{* * * *} \\
(-6-13)\end{array}$ & $\begin{array}{c}-03129 * * * \\
(-6.13)\end{array}$ \\
\hline insid_holding & & $\begin{array}{l}1.8485 \\
(0.81)\end{array}$ & $\begin{array}{c}4.0434 * * * \\
(259)\end{array}$ & $\begin{array}{c}39214^{* * *} \\
(267)\end{array}$ & & $\begin{array}{c}0.0712 \\
(0-56)\end{array}$ & $\begin{array}{c}0.4241 * * * \\
(3.62)\end{array}$ & $\begin{array}{c}0.4239 * * * \\
\text { (3.61) }\end{array}$ \\
\hline ceo_duality & & $\begin{array}{l}0.0992 \\
(0.86)\end{array}$ & $\begin{array}{l}0.0314 \\
(038)\end{array}$ & $\begin{array}{c}0.0381 \\
(0.5)\end{array}$ & & $\begin{array}{c}02107 * * * \\
(4.88)\end{array}$ & $\begin{array}{c}0.1749 * * * \\
(4.47)\end{array}$ & $\begin{array}{c}0.175 * * * \\
(4-47)\end{array}$ \\
\hline boand_indep & & $\begin{array}{l}-0.0637 \\
(-0.36)\end{array}$ & $\begin{array}{c}0.3648 * * * \\
(3.01)\end{array}$ & $\begin{array}{c}03565^{* * *} \\
(3.13)\end{array}$ & & $\begin{array}{c}-03436 * * * * \\
(-4.68)\end{array}$ & $\begin{array}{c}-0.3743^{* * * *} \\
(-558)\end{array}$ & $\begin{array}{c}-03742^{* * *} \\
(-557)\end{array}$ \\
\hline boand_size & & $\begin{array}{l}0.235 * \\
(1.66)\end{array}$ & $\begin{array}{c}0.4193^{* * *} \\
(4.02)\end{array}$ & $\begin{array}{c}0.4592^{* * *} \\
(4.68)\end{array}$ & & $\begin{array}{c}0.211^{* * *} \\
(431)\end{array}$ & $\begin{array}{l}0.0716 \\
(154)\end{array}$ & $\begin{array}{l}0.0723 \\
(155)\end{array}$ \\
\hline st_dummy & $\begin{array}{c}1.8183 * * * \\
(8.61)\end{array}$ & & $\begin{array}{c}18302^{* * *} \\
(8.89)\end{array}$ & $\begin{array}{c}1.8374^{* * *} \\
(9.49)\end{array}$ & $\begin{array}{c}0.6172^{* * *} \\
(4.35)\end{array}$ & & $\begin{array}{c}0.7786 * * * \\
(5.66)\end{array}$ & $\begin{array}{c}0.7787 * * * \\
(5.66)\end{array}$ \\
\hline _nd_dummy & $\begin{array}{c}\text { 4.4059*** } \\
\text { (13_42) }\end{array}$ & & $\begin{array}{c}4.769^{* * *} \\
(14.69)\end{array}$ & & $\begin{array}{l}0.6555 \\
(161)\end{array}$ & & $\begin{array}{l}0.2937 \\
(0.75)\end{array}$ & \\
\hline index_neturn & $\begin{array}{r}-0.1394 \\
(-0.78)\end{array}$ & & $\begin{array}{l}-0.0371 \\
(-0.21)\end{array}$ & $\begin{array}{l}-0.0984 \\
(-0.61)\end{array}$ & $\begin{array}{c}-0.6661^{* * *} \\
(-7.8)\end{array}$ & & $\begin{array}{c}-0.5741^{* * *} \\
(-697)\end{array}$ & $\begin{array}{c}-0.5743^{* * *} \\
(-697)\end{array}$ \\
\hline total assets & $\begin{array}{c}0.00002 \\
(0.28)\end{array}$ & & $\begin{array}{c}-0.0001 \\
(-13)\end{array}$ & $\begin{array}{c}-0.0001 \\
(-14)\end{array}$ & $\begin{array}{c}0.00003 \\
(0.67)\end{array}$ & & $\begin{array}{c}0.0001 * * * \\
(2.71)\end{array}$ & $\begin{array}{c}0.0001^{* * *} \\
(27)\end{array}$ \\
\hline roa & $\begin{array}{c}-33356^{* * *} \\
(-328)\end{array}$ & & $\begin{array}{c}-3.8377^{* * *} \\
(-392)\end{array}$ & $\begin{array}{c}-3.3131 * * * \\
(-358)\end{array}$ & $\begin{array}{c}-32235^{* * *} \\
(-11.14)\end{array}$ & & $\begin{array}{c}-3.1026 * * * \\
(-10.71)\end{array}$ & $\begin{array}{c}-3.0992^{* * *} \\
(-10.69)\end{array}$ \\
\hline ltd & $\begin{array}{c}0.4426 * * \\
(216)\end{array}$ & & $\begin{array}{c}0.5184^{* * *} \\
(2.63)\end{array}$ & $\begin{array}{c}0.5162^{* * *} \\
(279)\end{array}$ & $\begin{array}{c}0.7382^{* * *} \\
(7.34)\end{array}$ & & $\begin{array}{c}0.9665^{* * *} \\
(9.75)\end{array}$ & $\begin{array}{c}0.9666^{* * *} \\
(9.75)\end{array}$ \\
\hline pb & $\begin{array}{c}-0.1299 * * * * \\
(-277)\end{array}$ & & $\begin{array}{c}-0.162 * * * \\
(-3-4)\end{array}$ & $\begin{array}{c}-0.1477^{* * *} \\
(-329)\end{array}$ & $\begin{array}{c}-0.0442^{* * * *} \\
\quad(-7.2)\end{array}$ & & $\begin{array}{c}-0.0419^{* * * *} \\
(-7.05)\end{array}$ & $\begin{array}{c}-0.0419 * * * \\
(-7.04)\end{array}$ \\
\hline Year fixed effect & Yes & Yes & Yes & Yes & Yes & Yes & Yes & Yes \\
\hline R-Square & $5187 \%$ & $3.07 \%$ & $56.80 \%$ & $4182 \%$ & $18.63 \%$ & $6.48 \%$ & $25.23 \%$ & $25.07 \%$ \\
\hline
\end{tabular}


Table 7: Full-sanple Regressions with Dunqies

T able 7 shows the regressions on the full sample from 2010 to 2012, which reports the results from OIS regressions of CDS spread (equation 1, 2, 3 and 4) and Defiult p robability (equation 5, 6, 7 and 8) on a set of firms' corporate goremance variables and control variables. CDS spread and Default probability ane measured as Ln[Y/ (1-Y)] in the estimations, respectivety. Diffenent from T able 4, it inserts two dummy variables. st dummy equals to 1 if a firm is from Greece or Ineland, 0 otherw ise nd dummy equals to 1 if it is the Japanese firm with default issue, 0 otherw ise The measures of other variables are the same as those shown in Table $4 . * *, * *, *$ denote statistical significance at the $1 \%$, $5 \%$, and $10 \%$ kvels, respectively. $t$ values are reported in panentheses.

\begin{tabular}{|c|c|c|c|c|c|c|c|c|}
\hline & (1) & (2) & (3) & (4) & (5) & (6) & (7) & (8) \\
\hline Number of observations: & 325 & 325 & 325 & 322 & 1942 & 1942 & 1942 & 1939 \\
\hline Intercept & $\begin{array}{l}-3.6434 \\
(-3731)\end{array}$ & $\begin{array}{r}-4.2805 \\
(-1142)\end{array}$ & $\begin{array}{r}-4.2918 \\
(-1128)\end{array}$ & $\begin{array}{c}-5.058 \\
(-17.04)\end{array}$ & $\begin{array}{c}-39274 \\
(-148.66)\end{array}$ & $\begin{array}{r}-4.2749 \\
(-34.71)\end{array}$ & $\begin{array}{l}-39604 \\
(-33.19)\end{array}$ & $\begin{array}{l}-3.9652 \\
(-33.18)\end{array}$ \\
\hline insti_holding & & $\begin{array}{c}-03318 * * \\
(-2.04)\end{array}$ & $\begin{array}{c}-0.2552^{*} \\
(-165)\end{array}$ & $\begin{array}{l}-0.0448 \\
(-0.37)\end{array}$ & & $\begin{array}{c}-02875^{* * *} \\
(-5.1)\end{array}$ & $\begin{array}{c}-0301^{* * *} \\
(-5.86)\end{array}$ & $\begin{array}{l}-0.3 * * * \\
(-5.83)\end{array}$ \\
\hline insid_holding & & $\begin{array}{l}1.8485 \\
(0.81)\end{array}$ & $\begin{array}{l}22063 \\
(102)\end{array}$ & $\begin{array}{l}3.095^{*} \\
(186)\end{array}$ & & $\begin{array}{l}0.0712 \\
(056)\end{array}$ & $\begin{array}{c}0.4463^{* * *} \\
(3.78)\end{array}$ & $\begin{array}{c}0.4487^{* * *} \\
(3.8)\end{array}$ \\
\hline ceo_duality & & $\begin{array}{l}0.0992 \\
(0.86)\end{array}$ & $\begin{array}{r}0.0487 \\
(0.44)\end{array}$ & $\begin{array}{r}-0.0561 \\
(-0.65)\end{array}$ & & $\begin{array}{c}0.2107^{* * *} \\
(4.88)\end{array}$ & $\begin{array}{c}0.1609^{* * *} \\
(4.09)\end{array}$ & $\begin{array}{c}0.1599^{* * *} \\
(4.06)\end{array}$ \\
\hline boand_indep & & $\begin{array}{l}-0.0637 \\
(-036)\end{array}$ & $\begin{array}{l}0.0968 \\
(0.58)\end{array}$ & $\begin{array}{c}0.2866^{* *} \\
(222)\end{array}$ & & $\begin{array}{c}-03436 * * * \\
(-4.68)\end{array}$ & $\begin{array}{c}-0.3643^{* * *} \\
(-539)\end{array}$ & $\begin{array}{c}-0.3617^{* * *} \\
(-535)\end{array}$ \\
\hline boand_size & & $\begin{array}{l}0.235^{*} \\
(166)\end{array}$ & $\begin{array}{c}0.2807^{*} \\
(196)\end{array}$ & $\begin{array}{c}0.519 * * * \\
(4-67)\end{array}$ & & $\begin{array}{c}0.211 * * * \\
(431)\end{array}$ & $\begin{array}{c}0.0875^{*} \\
(1.86)\end{array}$ & $\begin{array}{c}0.0891 * \\
\text { (19) }\end{array}$ \\
\hline index_netum & $\begin{array}{c}-0.5467 * * \\
(-2.41)\end{array}$ & & $\begin{array}{c}-0.4434^{*} \\
(-193)\end{array}$ & $\begin{array}{c}-05239^{* * *} \\
(-296)\end{array}$ & $\begin{array}{c}-0.7154 * * * \\
(-8.41)\end{array}$ & & $\begin{array}{c}-0.6388 * * * \\
(-7.77)\end{array}$ & $\begin{array}{c}-0.6395^{* * *} \\
(-7.78)\end{array}$ \\
\hline total_assets & $\begin{array}{l}-0.0001 \\
(-124)\end{array}$ & & $\begin{array}{r}-0.0001 \\
(-164)\end{array}$ & $\begin{array}{c}-0.0002^{* * *} \\
(-268)\end{array}$ & $\begin{array}{c}0.00002 \\
(0-51)\end{array}$ & & $\begin{array}{c}0.0001^{* *} \\
(232)\end{array}$ & $\begin{array}{c}0.0001 * * \\
(23)\end{array}$ \\
\hline roa & $\begin{array}{c}-6.0277^{* * *} \\
(-4.6)\end{array}$ & & $\begin{array}{c}-6.4599 * * * \\
(-4.93)\end{array}$ & $\begin{array}{c}-55936 * * * \\
(-5.53)\end{array}$ & $\begin{array}{c}-33959 * * * \\
(-11.79)\end{array}$ & & $\begin{array}{c}-3.3313^{* * *} \\
(-1152)\end{array}$ & $\begin{array}{c}-3.3281^{* * *} \\
(-115)\end{array}$ \\
\hline ltd & $\begin{array}{c}0.5504^{* *} \\
(2.05)\end{array}$ & & $\begin{array}{c}0.6189^{* *} \\
(229)\end{array}$ & $\begin{array}{l}03155 \\
(151)\end{array}$ & $\begin{array}{c}0.72^{* * *} \\
(7.14)\end{array}$ & & $\begin{array}{c}0.9287 * * * \\
(934)\end{array}$ & $\begin{array}{c}0.9235^{* * *} \\
(927)\end{array}$ \\
\hline pb & $\begin{array}{c}-0.1737^{* * *} \\
(-2.78)\end{array}$ & & $\begin{array}{c}-0.167 * * \\
(-253)\end{array}$ & $\begin{array}{c}-0.1637^{* * *} \\
\quad(-322)\end{array}$ & $\begin{array}{c}-0.0444^{* * *} \\
(-72)\end{array}$ & & $\begin{array}{c}-0.0421^{* * *} \\
(-7.02)\end{array}$ & $\begin{array}{c}-0.042^{* * *} \\
(-7.01)\end{array}$ \\
\hline Year fixed effect & Yes & Yes & Yes & Yes & Yes & Yes & Yes & Yes \\
\hline Country fixed effect & Yes & Yes & Yes & Yes & Yes & Yes & Yes & Yes \\
\hline R-Square & $13.78 \%$ & $3.07 \%$ & $1635 \%$ & $24.91 \%$ & $17.73 \%$ & $6.48 \%$ & $2397 \%$ & $23.82 \%$ \\
\hline
\end{tabular}


Table 8: Enropean firms vs Asian firns

Table 8 shows the regressions on Emropean firms and Asian firms. In Panel A, the equation (1), (2) and (3) use La [Y/ (1-Y)] as the measure of CDS spread as dependent variable, while the equation (4), (5) and (6) use Ln [Y/(1-Y)] as the measure of Defanlt probability as dependent variable. fn Panel B, the first four equations regress on CDS spread and the rest regress on defanlt probability. st dummy equals to 1 if a firm is from Greece or Ireland, 0 otherwise nd dummy equals to 1 if it is the Japanese firm with defanlt issue, 0 otherwise. The measures of other variables ane the same as those shown in Table $4 . * * ;, * * *$ denote statistical significanoe at the $1 \%, 5 \%$, and $10 \%$ kevels, respectively. $t$ values are reported in parentheses.

\begin{tabular}{|c|c|c|c|c|c|c|}
\hline \multicolumn{7}{|c|}{ Pand A (Enropean firms) } \\
\hline & (1) & (2) & (3) & (4) & (5) & (6) \\
\hline Number of observations: & 143 & 143 & 143 & 528 & 528 & 528 \\
\hline Intercept & $\begin{array}{l}-3.5038 \\
(-255)\end{array}$ & $\begin{array}{l}-3.6889 \\
(-5.69)\end{array}$ & $\begin{array}{l}-4.4757 \\
(-7.83)\end{array}$ & $\begin{array}{c}-4.1053 \\
(-71.12)\end{array}$ & $\begin{array}{r}-49994 \\
(-19.16)\end{array}$ & $\begin{array}{r}-4.6227 \\
(-17.88)\end{array}$ \\
\hline insti_holding & & $\begin{array}{c}-0.6488 * * * \\
(-3.09)\end{array}$ & $\begin{array}{c}-0.1709 \\
(-0.97)\end{array}$ & & $\begin{array}{c}-03778^{* * *} \\
(-4.53)\end{array}$ & $\begin{array}{c}-0.236^{* * *} \\
(-3.13)\end{array}$ \\
\hline insid_holding & & $\begin{array}{c}-1.5312 \\
(-0.6)\end{array}$ & $\begin{array}{l}1.4477 \\
(0.68)\end{array}$ & & $\begin{array}{c}-1.0008^{* * *} \\
(-394)\end{array}$ & $\begin{array}{r}-0.2065 \\
(-0.81)\end{array}$ \\
\hline ceo_duality & & $\begin{array}{c}-0.0438 \\
(-0.22)\end{array}$ & $\begin{array}{r}-0.1003 \\
(-0.63)\end{array}$ & & $\begin{array}{c}-0.0779 \\
(-0.7)\end{array}$ & $\begin{array}{l}-0.002 \\
(-0.02)\end{array}$ \\
\hline boand_indep & & $\begin{array}{c}-1.0244^{* * *} \\
(-3.4)\end{array}$ & $\begin{array}{l}-0.417 \\
(-1.64)\end{array}$ & & $\begin{array}{c}-0.0505 \\
(-0.36)\end{array}$ & $\begin{array}{c}-0.0164 \\
(-0.13)\end{array}$ \\
\hline boand_size & & $\begin{array}{c}0.3904^{*} \\
(1.82)\end{array}$ & $\begin{array}{c}0.5492^{* * *} \\
\text { (3) }\end{array}$ & & $\begin{array}{c}0.5028^{* * *} \\
(5.46)\end{array}$ & $\begin{array}{c}0.2718^{* * *} \\
(2.96)\end{array}$ \\
\hline _st_dummy & $\begin{array}{c}1.5313^{* * *} \\
(6.34)\end{array}$ & & $\begin{array}{c}1.4583^{* * *} \\
(5.87)\end{array}$ & $\begin{array}{c}0.8192^{* * *} \\
(5.85)\end{array}$ & & $\begin{array}{c}0.8215^{* * *} \\
(593)\end{array}$ \\
\hline index_retum & $\begin{array}{r}-0.2203 \\
(-0.78)\end{array}$ & & $\begin{array}{c}0.0974 \\
(0.35)\end{array}$ & $\begin{array}{c}-0.6322^{* * * *} \\
(-4.24)\end{array}$ & & $\begin{array}{c}-0.4963^{* * *} \\
(-3.29)\end{array}$ \\
\hline total_assets & $\begin{array}{r}-0.0001 \\
(-1.64)\end{array}$ & & $\begin{array}{c}-0.0002^{* * * *} \\
(-2.64)\end{array}$ & $\begin{array}{c}0.0002^{* * *} \\
(4.05)\end{array}$ & & $\begin{array}{c}0.0002^{* * *} \\
(2.66)\end{array}$ \\
\hline roa & $\begin{array}{c}-4.148^{* *} \\
(-2.3)\end{array}$ & & $\begin{array}{c}-3.4924^{*} \\
(-1.97)\end{array}$ & $\begin{array}{c}-3.0747^{* * * *} \\
(-5.63)\end{array}$ & & $\begin{array}{c}-2.6474^{* * *} \\
(-4.84)\end{array}$ \\
\hline ltd & $\begin{array}{c}0.4581 \\
(1.47)\end{array}$ & & $\begin{array}{l}0.1691 \\
(0.52)\end{array}$ & $\begin{array}{c}0.3152^{*} \\
(1.93)\end{array}$ & & $\begin{array}{c}0.4309^{* * *} \\
(2.63)\end{array}$ \\
\hline $\mathbf{p b}$ & $\begin{array}{c}-0.2999^{* * *} \\
(-3.17)\end{array}$ & & $\begin{array}{c}-0.2932^{* * *} \\
(-3.12)\end{array}$ & $\begin{array}{c}-0.0657^{* * * *} \\
(-3.05)\end{array}$ & & $\begin{array}{c}-0.0518^{* *} \\
(-2.25)\end{array}$ \\
\hline Year fixed effect & Yes & Yes & Yes & Yes & Yes & Yes \\
\hline R-Square & $47.71 \%$ & $19.46 \%$ & $53.73 \%$ & $30.63 \%$ & $1435 \%$ & $33.55 \%$ \\
\hline
\end{tabular}


Table 8 continued:

\begin{tabular}{|c|c|c|c|c|c|c|c|c|}
\hline \multicolumn{9}{|c|}{ Pand B (Asian firms) } \\
\hline & (1) & (2) & (3) & (4) & (5) & (6) & $(7)$ & (8) \\
\hline Number of observations: & 154 & 154 & 154 & 151 & 1232 & 1232 & 1232 & 1229 \\
\hline \multirow[t]{2}{*}{ Intercept } & -4.0284 & -3.6039 & -49804 & $-5 \_1969$ & -3.8726 & -3.6274 & -35517 & -35536 \\
\hline & (-41.11) & $(-6.2)$ & $(-1256)$ & $\left(-15 \_12\right)$ & $(-12324)$ & $(-21.89)$ & $(-2299)$ & $(-2297)$ \\
\hline \multirow[t]{2}{*}{ insti_holding } & & -0.0303 & 0.2874 & 022999 & & -0.1305 & $-0.2783^{* * *}$ & $-0.2787 * * *$ \\
\hline & & $(-0.1)$ & (13) & (158) & & $(-1.4)$ & $(-325)$ & $(-326)$ \\
\hline \multirow[t]{2}{*}{ insid_holding } & & 2.2371 & 3.4511 & 3.6286 & & $0.4882 * * *$ & $0.4977 *$ & $0.4975 *$ \\
\hline & & $(0.49)$ & (1.14) & (139) & & (3.17) & (354) & (3.53) \\
\hline \multirow[t]{2}{*}{ ceo_duality } & & $03896^{* *}$ & $0.2902 * *$ & $02916^{* * * *}$ & & $0.1065 * *$ & $0.0757^{*}$ & $0.0759^{*}$ \\
\hline & & $(2.27)$ & (2-46) & $(2.86)$ & & (2.1) & (1.66) & (1.66) \\
\hline \multirow[t]{2}{*}{ board_indep } & & 0.3215 & $0.9831^{* * *}$ & $0.8889 * * *$ & & $-03784^{* * * *}$ & $-0264^{* * * *}$ & $-02641 * * *$ \\
\hline & & $(0.92)$ & (393) & (4.11) & & $(-356)$ & $(-2.68)$ & $(-2.67)$ \\
\hline \multirow[t]{2}{*}{ board_size } & & -0.2651 & 02076 & $02851^{* *}$ & & -0.075 & -0.0939 & -0.0931 \\
\hline & & $(-1.14)$ & (128) & $(2.04)$ & & $(-1.11)$ & $(-151)$ & $(-1.49)$ \\
\hline \multirow[t]{2}{*}{ _nd_dummy } & $45829 * * *$ & & $4913^{* * * * *}$ & & 03513 & & 0.1482 & \\
\hline & (13.59) & & (14.87) & & $(0.88)$ & & (038) & \\
\hline \multirow[t]{2}{*}{ index_retum } & 0.076 & & 0.0305 & -0.0955 & $-0.6749^{* * * *}$ & & $-0.6138^{* * * *}$ & $-0.6141 * * *$ \\
\hline & (03) & & (0.13) & $(-0.46)$ & $(-657)$ & & $(-6.08)$ & $(-6.07)$ \\
\hline \multirow[t]{2}{*}{ total_assets } & 0.0001 & & 0.00007 & 0.0001 & -0.00006 & & 0.00006 & 0.00006 \\
\hline & (091) & & $(0.6)$ & $(0.64)$ & $(-0.8)$ & & $(0.76)$ & $(0.76)$ \\
\hline \multirow[t]{2}{*}{ roa } & $-25273^{* * *}$ & & $-3.6561^{* * * *}$ & $-2.7702^{* * *}$ & $-3.429 * * * *$ & & $-35562^{* * * *}$ & $-3 \_551^{* * * *}$ \\
\hline & (-198) & & $(-2.67)$ & $(-233)$ & (-8_12) & & $(-832)$ & $(-83)$ \\
\hline \multirow[t]{2}{*}{ ltd } & 03165 & & 0.1494 & 0.1866 & $13709^{* * * *}$ & & $1.4312 *$ & $1.4312 *$ \\
\hline & (1_08) & & $(0.48)$ & $(0.69)$ & (1032) & & (10.76) & (10.75) \\
\hline \multirow[t]{2}{*}{ pb } & -0.0585 & & $-0.1515^{* * *}$ & $-0.1225^{* * *}$ & $-0.0498 * * *$ & & $-0.0492^{* * * *}$ & $-0.0491 * * *$ \\
\hline & $(-097)$ & & $(-2.29)$ & $(-2.13)$ & $(-7.81)$ & & $(-7.61)$ & (-7.6) \\
\hline Year fixed effect & Yes & Yes & Yes & Yes & Yes & Yes & Yes & Yes \\
\hline R-Square & $58.60 \%$ & $6.29 \%$ & $65.46 \%$ & $23.67 \%$ & $19.89 \%$ & $4.21 \%$ & $23.85 \%$ & $23.62 \%$ \\
\hline
\end{tabular}


Table 9: Entupean firns vs Asian fins

Table 9 shows the regressions on Furopemn firms and A sian firms. In Panel A, the equation (1), (2) and (3) useLn [Y / (1-Y)] as the measure of CDS spread as dependent variable, while the equation (4), (5) and (6) use Ln [Y / (1-Y)] as the measure of Default probability as dependent variable In Pand B, the first four equations regress on CDS spread and the rest regress on defalt probability

st_dummy equals to 1 if a firm is from Greece or Iretand, 0 otherwise_nd dummy equals to 1 if it is the Japanese firm with defanlt issue, 0 otherwise The measures of other variables are the same as those shown in T able 4. ***, **, * denote statistical significance at the $1 \%, 5 \%$, and $10 \%$ levels, respectively $t$ values are reported in panentheses.

\begin{tabular}{|c|c|c|c|c|c|c|}
\hline \multicolumn{7}{|c|}{ Pand A (European firms) } \\
\hline & (1) & (2) & (3) & (4) & (5) & (6) \\
\hline Number of observations: & 143 & 143 & 143 & 528 & 528 & 528 \\
\hline Interopt & $\begin{array}{l}-32837 \\
(-2178)\end{array}$ & $\begin{array}{l}-3.6889 \\
(-5.69)\end{array}$ & $\begin{array}{l}-3.4201 \\
(-5.63)\end{array}$ & $\begin{array}{c}-4.006 \\
(-7039)\end{array}$ & $\begin{array}{l}-4.9994 \\
(-19.16)\end{array}$ & $\begin{array}{r}-4.5335 \\
(-17.01)\end{array}$ \\
\hline insti_holfing & & $\begin{array}{c}-0.6488 * * * \\
(-3.09)\end{array}$ & $\begin{array}{c}-03748^{*} \\
(-193)\end{array}$ & & $\begin{array}{c}-03778^{* * *} \\
(-4.53)\end{array}$ & $\begin{array}{c}-02297 * * * \\
(-295)\end{array}$ \\
\hline insid_holfing & & $\begin{array}{c}-15312 \\
(-0.6)\end{array}$ & $\begin{array}{r}-0.0974 \\
(-0.04)\end{array}$ & & $\begin{array}{c}-1.0008^{* * *} \\
(-3.94)\end{array}$ & $\begin{array}{r}-0.1744 \\
(-0.66)\end{array}$ \\
\hline coo_duality & & $\begin{array}{l}-0.0438 \\
(-0.22)\end{array}$ & $\begin{array}{l}-0.1622 \\
(-0.91)\end{array}$ & & $\begin{array}{c}-0.0779 \\
(-0.7)\end{array}$ & $\begin{array}{l}-0.0647 \\
(-0.63)\end{array}$ \\
\hline board_indep & & $\begin{array}{c}-1.0244^{* * *} \\
(-3.4)\end{array}$ & $\begin{array}{c}-0.8395^{* * *} \\
(-3.06)\end{array}$ & & $\begin{array}{l}-0.0505 \\
(-0.36)\end{array}$ & $\begin{array}{l}-0.0459 \\
(-035)\end{array}$ \\
\hline boand_size & & $\begin{array}{c}03904^{*} \\
(1.82)\end{array}$ & $\begin{array}{c}03967^{*} \\
(196)\end{array}$ & & $\begin{array}{c}0.5028 * * * \\
(5.46)\end{array}$ & $\begin{array}{c}0.2845^{* * *} \\
\text { (3) }\end{array}$ \\
\hline index_neturn & $\begin{array}{c}-0.8759 * * * \\
(-296)\end{array}$ & & $\begin{array}{r}-0.4401 \\
(-148)\end{array}$ & $\begin{array}{c}-0.8245 * * * \\
(-55)\end{array}$ & & $\begin{array}{c}-0.69^{* * *} \\
(-4.54)\end{array}$ \\
\hline total_assets & $\begin{array}{c}-0.0002^{* * *} \\
(-269)\end{array}$ & & $\begin{array}{c}-0.0003^{* * *} \\
(-3-44)\end{array}$ & $\begin{array}{c}0.0002^{* * *} \\
(326)\end{array}$ & & $\begin{array}{c}0.0001^{*} \\
(193)\end{array}$ \\
\hline roa & $\begin{array}{c}-8.135^{* * *} \\
(-4.25)\end{array}$ & & $\begin{array}{c}-63968 * * * \\
(-336)\end{array}$ & $\begin{array}{c}-3.6785 * * * \\
(-6.65)\end{array}$ & & $\begin{array}{c}-32326 * * * \\
(-5.82)\end{array}$ \\
\hline Hd & $\begin{array}{l}0.1527 \\
(0.44)\end{array}$ & & $\begin{array}{l}-0328 \\
(-0.92)\end{array}$ & $\begin{array}{l}0.1505 \\
(091)\end{array}$ & & $\begin{array}{l}0.2616 \\
(157)\end{array}$ \\
\hline pb & $\begin{array}{c}-03025^{* * *} \\
(-282)\end{array}$ & & $\begin{array}{c}-0.3185^{* * *} \\
\left(-3 \_03\right)\end{array}$ & $\begin{array}{c}-0.0673^{* * *} \\
\left(-3 \_02\right)\end{array}$ & & $\begin{array}{c}-0.0554^{* *} \\
(-233)\end{array}$ \\
\hline Year fixed effect & Yes & Yes & Yes & Yes & Yes & Yes \\
\hline Country fixed effect & Yes & Yes & Yes & Yes & Yes & Yes \\
\hline R-Square & $32.26 \%$ & $19.46 \%$ & $4154 \%$ & $26.07 \%$ & $1435 \%$ & $29.03 \%$ \\
\hline
\end{tabular}


Table 9 continned:

\begin{tabular}{|c|c|c|c|c|c|c|c|c|}
\hline \multicolumn{9}{|c|}{ Pand B (Asian firms) } \\
\hline & (1) & (2) & (3) & (4) & (5) & (6) & (7) & (8) \\
\hline Number of observations: & 154 & 154 & 154 & 151 & 1232 & 1232 & 1232 & 1229 \\
\hline \multirow[t]{2}{*}{ Intercept } & -39616 & -3.6039 & -4.0815 & -5.1969 & -3.8726 & -3.6274 & -3.5493 & -3.5536 \\
\hline & $(-27.04)$ & $(-6.2)$ & $(-654)$ & $(-15.12)$ & $(-123.25)$ & $(-21.89)$ & $(-23)$ & $(-22.97)$ \\
\hline \multirow[t]{2}{*}{ insti_holding } & & -0.0303 & -0.4137 & 0.2999 & & -0.1305 & $-0.2798 * * *$ & $-0.2787 * * *$ \\
\hline & & $(-0.1)$ & $(-1.21)$ & (158) & & $(-1.4)$ & $(-3.28)$ & $(-3.26)$ \\
\hline \multirow[t]{2}{*}{ insid_holding } & & 2.2371 & 23825 & 3.6286 & & $0.4882^{* * *}$ & $0.4955^{* * *}$ & $0.4975^{* * *}$ \\
\hline & & (0.49) & (0.49) & (139) & & (3.17) & (3.53) & (3.53) \\
\hline \multirow[t]{2}{*}{ ceo_duality } & & $03896 * *$ & $0.3777 * *$ & $0.2916^{* * *}$ & & $0.1065^{* *}$ & $0.0762^{*}$ & $0.0759^{*}$ \\
\hline & & $(2.27)$ & (2.01) & $(2.86)$ & & (2.1) & (1.67) & (1.66) \\
\hline \multirow[t]{2}{*}{ boand_indep } & & 0.3215 & 0.5181 & $0.8889^{* * *}$ & & $-0.3784 * * *$ & $-0.2661^{* * *}$ & $-0.2641 * * *$ \\
\hline & & $(0.92)$ & (131) & (4.11) & & $(-3.56)$ & $(-2.7)$ & $(-2.67)$ \\
\hline \multirow[t]{2}{*}{ boand_size } & & -0.2651 & -0.0123 & $0.2851^{* *}$ & & -0.075 & -0.0946 & -0.0931 \\
\hline & & $(-1.14)$ & $(-0.05)$ & $(2.04)$ & & $(-1.11)$ & $(-1.52)$ & $(-1.49)$ \\
\hline \multirow[t]{2}{*}{ index_return } & 0.1254 & & 0.146 & -0.0955 & $-0.675^{* * *}$ & & $-0.6135 * * *$ & $-0.6141 * * *$ \\
\hline & $(033)$ & & $(039)$ & $(-0.46)$ & $(-6.57)$ & & $(-6.08)$ & $(-6.07)$ \\
\hline \multirow[t]{2}{*}{ total_assets } & 0.0001 & & 0.0002 & 0.0001 & -0.0001 & & 0.0001 & 0.0001 \\
\hline & (0.5) & & (1.28) & $(0.64)$ & $(-0.81)$ & & $(0.77)$ & $(0.76)$ \\
\hline \multirow[t]{2}{*}{ roa } & $-3.4331^{*}$ & & $-4.5053^{* *}$ & $-2.7702^{* *}$ & $-3.4374 * * *$ & & $-35569 * * *$ & $-3.551 * * *$ \\
\hline & $(-1.8)$ & & $(-2.07)$ & $(-233)$ & $(-8.15)$ & & $(-8.33)$ & $(-8.30)$ \\
\hline \multirow[t]{2}{*}{ ltd } & $1.0236^{* *}$ & & $0.9057^{*}$ & 0.1866 & $13801 * * *$ & & $1.436 * * *$ & $1.4312^{* * *}$ \\
\hline & (236) & & $(1.85)$ & $(0.69)$ & $(10.42)$ & & (10.85) & (10.75) \\
\hline \multirow[t]{2}{*}{ pb } & -0.1249 & & -0.1036 & $-0.1225^{* *}$ & $-0.0498 * * *$ & & $-0.0492^{* * *}$ & $-0.0491 * * *$ \\
\hline & $(-139)$ & & $(-0.98)$ & $(-2.13)$ & $(-7.82)$ & & $(-7.62)$ & $(-7.60)$ \\
\hline Year fixed effect & Yes & Yes & Yes & Yes & Yes & Yes & Yes & Yes \\
\hline Comntry fixed effect & Yes & Yes & Yes & Yes & Yes & Yes & Yes & Yes \\
\hline R-Square & $6.57 \%$ & $6.29 \%$ & $11.67 \%$ & $23.67 \%$ & $19.84 \%$ & $4.21 \%$ & $23.84 \%$ & $23.62 \%$ \\
\hline
\end{tabular}


Appendix A

Definition of variables.

\begin{tabular}{|c|c|c|}
\hline Variables & Definition & Sources \\
\hline institutional holdings & Percentage of Shares Outstanding held by institutions.Based on holdings data collected by Bloomberg. & Bloomberg \\
\hline insider holdings & Percentage of outstanding shares currently held by insiders. Based on holdings data collected by Bloomberg. & Bloomberg \\
\hline board independence & Indep endent directors as a percentage of total board membership. & Bloomberg \\
\hline board size & Number of Directors on the company's board, as reported by the company. Full time Directors only. & Bloomberg \\
\hline ceo duality & $\begin{array}{l}\text { Dummy variable indicating whether the company's Chief Executive Officer is also Chairman of the Board, as } \\
\text { reported by the company. }\end{array}$ & Bloomberg \\
\hline total assets & The total of all short and long-term assets as reported on the Balance Sheet. & Bloomberg \\
\hline roa & $\begin{array}{l}\text { Indicator of how profitable a company is relative to its total assets, in percentage. We define return on assets } \\
\text { as returns divided by total assets each year from } 2010 \text { to } 2012 \text {. }\end{array}$ & Bloomberg \\
\hline ltd & $\begin{array}{l}\text { Measures the percentage of long term debt to total assets. Unit: Actual. It is calculated as: (Long Term } \\
\text { Borrowings / Total Assets) } * 100\end{array}$ & Bloomberg \\
\hline $\mathrm{pb}$ & $\begin{array}{l}\text { Ratio of the stock price to the book value per share. Calculated as: Price to Book Ratio = Last Price } / \text { Book } \\
\text { Value Per Share }\end{array}$ & Bloomberg \\
\hline cds spread & $\begin{array}{l}\text { CDS premium containing information on the default probability associated with a reference entity, which is } \\
\text { collected by Markit Inc.. }\end{array}$ & Markit Group \\
\hline
\end{tabular}




\section{Appendix B}

Generalized Method of Moments (GMM) estimation overidentification tests:

\begin{tabular}{|c|c|c|c|c|}
\hline \multicolumn{5}{|c|}{ Panel A: Results including the Japanese highest-CDS firm } \\
\hline Variable & Coefficient & Std. Error & $\mathrm{t}$-Statistic & Prob. \\
\hline INSTI_HOLDING & -6.9992 & 3.165 & -2.2115 & 0.0278 \\
\hline INDEX_RETURN & 0.0418 & 1.1645 & 0.0359 & 0.9714 \\
\hline INSID_HOLDING & -12.5475 & 12.3906 & -1.0127 & 0.3121 \\
\hline CEO_DUALITY & -2.4383 & 1.4698 & -1.6589 & 0.0982 \\
\hline BOARD_INDEP & -11.4371 & 6.862 & -1.6667 & 0.0966 \\
\hline BOARD_SIZE & 0.6188 & 0.9042 & 0.6844 & 0.4943 \\
\hline TOTAL_ASSETS & 0.3373 & 0.3397 & 0.993 & 0.3216 \\
\hline ROA & -0.5393 & 8.1962 & -0.0658 & 0.9476 \\
\hline LTD & 1.0387 & 1.366 & 0.7604 & 0.4476 \\
\hline PB & 0.4181 & 0.464 & 0.9012 & 0.3682 \\
\hline
\end{tabular}

J-statistic: 0.5086

$\operatorname{Prob}(J-s t a t i s t i c): 0.4758$

\begin{tabular}{|c|c|c|c|c|}
\hline \multicolumn{5}{|c|}{ Panel B: Results excluding the Japanese highest-CDS firm } \\
\hline Variable & Coefficient & Std. Error & t-Statistic & Prob. \\
\hline INSTI_HOLDING & -0.2459 & 0.3355 & -0.7329 & 0.4642 \\
\hline INDEX_RETURN & -0.0931 & 0.2441 & -0.3815 & 0.7031 \\
\hline INSID_HOLDING & 2.7587 & 1.7322 & 1.5926 & 0.1123 \\
\hline CEO_DUALITY & 0.0642 & 0.0849 & 0.7571 & 0.4496 \\
\hline BOARD_INDEP & 0.2852 & 0.1429 & 1.9952 & 0.047 \\
\hline BOARD_SIZE & 0.2838 & 0.1352 & 2.1 & 0.0366 \\
\hline TOTAL_ASSETS & -0.0227 & 0.0269 & -0.8417 & 0.4006 \\
\hline ROA & -3.2829 & 1.1172 & -2.9385 & 0.0036 \\
\hline LTD & 0.4359 & 0.2363 & 1.845 & 0.0661 \\
\hline PB & -0.1394 & 0.0512 & -2.7229 & 0.0069 \\
\hline
\end{tabular}

J-statistic: 1.5214

Prob(J-statistic): 0.2174 
Generalized Method of Moments (GMM) estimation endogeneity tests:

\begin{tabular}{|c|c|c|c|}
\hline \multicolumn{4}{|c|}{ Panel A: Results including the Jap anese highest-CDS firm } \\
\hline & Value & df & Probability \\
\hline Difference in J-stats & 0.4633 & 1 & 0.4961 \\
\hline \multicolumn{4}{|l|}{ J-statistic summary: } \\
\hline & \multicolumn{3}{|c|}{ Value } \\
\hline Restricted J-statistic & \multicolumn{3}{|c|}{2.9672} \\
\hline Unrestricted J-statistic & \multicolumn{3}{|c|}{2.504} \\
\hline \multicolumn{4}{|c|}{ Panel B: Results excluding the Jap anese highest-CDS firm } \\
\hline & Value & $\mathrm{df}$ & Probability \\
\hline Difference in J-stats & 0.5134 & 1 & 0.4737 \\
\hline \multicolumn{4}{|l|}{ J-statistic summary: } \\
\hline \multicolumn{4}{|c|}{ Value } \\
\hline Restricted J-statistic & \multicolumn{3}{|c|}{1.8952} \\
\hline Unrestricted J-statistic & \multicolumn{3}{|c|}{1.3818} \\
\hline
\end{tabular}

